\title{
Obtainment and Study of the Toxicity of Perillyl Alcohol Nanoemulsion on Zebrafish (Danio rerio)
}

\begin{abstract}
Introduction: Perillyl alcohol (POH) is a hydroxylated monocyclic monoterpene found in lemon and lavender essential oils, among others. It's widely recognized by antitumoral activity. Despite the great potential of nanoformulations for pharmaceutics, to the date the obtainment a perillyl alcohol-nanoemulsion $(\mathrm{NPOH})$ and its toxicity investigation were not previously reported. On this context, the present study aim to evaluate the toxicity of NPOH on zebrafish (Danio rerio). Lethal concentration (LC50), effects on behaviour and acute administrations effects (48h) on histopathological parameters of the gills, liver and kidneys were performed.
\end{abstract}

Results: Exposure to different concentrations of NPOH (25, 35, 50 e $125 \mu \mathrm{g} / \mathrm{L}$ expressed as POH content) allowed determination of LC50 $=33.4 \mu \mathrm{g} / \mathrm{L}$. Moreover, $\mathrm{NPOH}$ at 50 and $125 \mu \mathrm{g} / \mathrm{L}$ induced $100 \%$ of mortality, in addition the alterations of behavior. NPOH at 25 and $35 \mu \mathrm{g} / \mathrm{L}$ induced higher damage to gills tissue when compared to remaining concentrations and control group (surfactant at 125 $\mu \mathrm{g} / \mathrm{L})(\mathrm{p}<0.001, \mathrm{p}<0.01$ and $\mathrm{p}<0.05$, Anova, Tukey-Kramer test). NPOH at $25,35 \mathrm{e} 50 \mu \mathrm{g} / \mathrm{L}$ induced significative damage to liver tissue, when compared to control $(\mathrm{p}<0.01$ and $\mathrm{p}<0.05)$. No significant histopathological alterations were observed in kidneys. Thus, our results suggest that NPOH present toxicity pattern in accordance to nanoformulations and xenobiotics.

Keywords: Danio rerio; Perillyl alcohol; Nanoemulsion; Toxicity; Histopathology

Research Article
Volume 4 Issue 4 - 2016
Gisele Custódio de Souza' ${ }^{1}$, Jonatas Lobato
Duarte ${ }^{1}$, Caio Pinho Fernandes ${ }^{1}$, Josué
Arturo Velázquez Moyado o' , Andrés
Navarrete ${ }^{2}$ and José Carlos Tavares
Carvalho ${ }^{1 *}$
${ }^{1}$ Departamento de Ciências Biológicas e da Saúde,
Universidade Federal do Amapá, Brazil
${ }^{2}$ Departamento de Farmacia, Universidad Nacional Autónoma
de México, México
*Corresponding author: José Carlos Tavares Carvalho,
Departamento de Ciências Biológicas e da Saúde,
Universidade Federal do Amapá, Laboratorio de Pesquisa
em Fármacos, Curso de Farmácia, Rodovia Juscelino
Kubitscheck, km 02, CEP 68902-280, Macapá, Amapá, Brazil,
Email: farmacos@unifap.br
Received: November 17, 2016 | Published: December 07,
2016

\section{Introduction}

Toxicity is a relative property of a chemical substance that refers to its potential damage to living organisms; it is being related to its concentration and the exposure time [1]. The expression of toxicity of a chemical substance depends on exposure characteristics and its behaviour on the organism, associated to transport mechanisms and interaction with targetsite and tissues. Thus, toxicity only occurs if the agent is able to reach specific targets at sufficient concentrations in order to induce some effects [2].

Danio rerio has been considered a potential model for several human diseases $[3,4]$. Toxicity determination is a critical step for the development of new pharmaceuticals, considering that toxicity has a high impact of clinical trials. Adults and embryos of $D$. rerio are both used for general and specific tissue toxicity studies [5-7]. Rubinstein et al. [8] suggest that evaluation of drug toxicity using $D$. rerio should be included in pre-clinical studies. Based on this context, the application of this model have been increased in the last years, in both phases embryonic and adult many studies, have shown significative alterations of animal development, behavioural and histological aspects.

Histology is considered an important method to diagnose direct and indirect effects that affect animal tissues. Its combination with other analysis allows a better comprehension of several conditions, it is crucial to define target organs in order to obtain relevant results [9].
According to Lins et al. [10] the main organs affected by the toxic agents are gills, liver and kidneys, this is also useful to indicate alterations induced by chronic exposure to these agents. Liver and kidneys are associated to the metabolism and excretion of xenobiotics. Most of $D$. rerio model tested nanoformulations which are metal-based (iron, copper, titanium dioxide), indicating the need to increase toxicological studies of other nanoformulations, including those with natural products $[11,12]$. The evaluation of the toxicity of these nanoformulations is extremely important for human health, since its reach to organs in the body is facilitated by its small size, and several studies have shown that nanoparticles can to reach the brain and cause tissue damage $[13,14]$.

Limonene is a monocyclic monoterpene that is found in citric fruits, mainly lemon and orange. This low toxic compound has chemo preventive and chemotherapeutic activities against several tumor cell lines, due to its ability to inhibit post-traumatic isoprenylation of GTPase, including Ras family members [15-17]. The high dose of limonene required for the beneficial effects have limited their use. For this reason, other mono terpenes began to be investigated, especially its metabolites perillyl alcohol $(\mathrm{POH})$ and perillyl acid (PA).

The $\mathrm{POH}$ is isoprenylation inhibitor of Ras protein, act in the control of cell proliferation, in the activation of post apoptotic pathways, and blocking the cell cycle of different tumor cells in vitro [16,18-20]. The $\mathrm{POH}$ is also found in many essential oils, such as lemon, lavender, spearmint, sage, celery seed, bergamot, ginger and cherry. It has potent antitumor activity, acting in the 
regression of different tumours, including breast, pancreatic and brain [21-23]. It also presents radiosensibilizing effects and significant angiogenic inhibition [24,25]. It has already been described several antitumor activities for $\mathrm{POH}$ and its ability to block the cell cycle and cause apoptosis in leukemic cells, lung tumor, adenocarcinoma, activate apoptotic proteins, inhibit metastasis in glial cells, inhibit proliferation of lung cancer cells, inhibit migration and proliferation of breast tumor cells $[18,20,21,26-31]$.

In a recent study, Salazar et al. [32] reported that intranasal administration of $80 \mu \mathrm{g}$ of $\mathrm{POH}$ per day, activates the immune system and no clinical signs of the recurrent gliomas, such as weight loss, convulsions, and diarrheal were observed, and when performing morphological analysis of tissue found that there were no changes in the tissues. Thus, considering previous nonclinical and clinical data of $\mathrm{POH}$, the aim of the present study was to evaluate acute toxicological effects of its nanoemulsion (NPOH) on Danio rerio.

\section{Materials and Methods}

This study was approved by the Ethics Committee for Animal Experimentation of Amapá Federal University (Brazil) under the register number 005/2014.

\section{Perillyl alcohol nanoemulsion (NPOH)}

Nano-emulsification method: It was used low energy method for obtainment the nanoemulsions with some modifications [33]. Oil phase was constituted by $\mathrm{POH}$ and surfactants, while aqueous phase was constituted by deionized water. Oil phase was submitted to magnetic stirring $(400 \mathrm{rpm})$ for $30 \mathrm{~min}$. After this period, aqueous phase was added drop-wise and system was stirred for $60 \mathrm{~min}$. Each nanoemulsion has a final mass of $50 \mathrm{~g}$ and was constituted by $5 \%(\mathrm{w} / \mathrm{w})$ of $\mathrm{POH}, 5 \%(\mathrm{w} / \mathrm{w})$ of surfactants and $90 \%(\mathrm{w} / \mathrm{w})$ of water.

Surfactants ratio optimization: Different surfactants ratio was prepared in order to obtain specific Hydrophile-Lipophile Balance values (HLB). Sorbitan monooleate (most hydrophobic, HLB = 4.3) and polysorbate 80 (most hydrophilic, HLB $=15$ ) were employed and three different HLB values were obtained as follows: HLB 7 (3.74\% of sorbitan monooleate and $1.26 \%$ of polysorbate 80 ); HLB 8 (3.28\% of sorbitan monooleate and $1.72 \%$ of polysorbate 80 ); HLB 9 (2.8\% of sorbitan monooleate and $2.2 \%$ of polysorbate 80 ). Total surfactant amount corresponded to $5 \%(w / w)$ of each nanoemulsion.

Nanoemulsion characterization: Droplet size and Polydispersity index of the nanoemulsions (NPOH) was determined by photon correlation spectroscopy (Zetasizer ZS, Malvern, UK). Nanoemulsions were diluted with water for injection $(1: 25)$. Measurements were made by triplicate and average droplet size was expressed as the mean diameter \pm SD.

\section{Acute Toxicity Assay}

\section{Animals}

D rerio were purchased from Aqua New Aquários e Peixes Ltda. ME (PE, Brazil), according to authorization no 526140011289802 (7 May 2014) under register number no 82957 obtained from Brazilian Institute of Environment and Renewable Natural
Resources - IBAMA.

\section{Evaluation of behavioural parameters under normal conditions}

Total of 90 animals were used for behavioural and histological analysis. The experiments were performed with adults (1214 months age). D. rerio were maintained under controlled conditions $\left(26 \pm 10^{\circ} \mathrm{C}\right.$ and 10:14 light: dark cycle). Normalized water was employed [34], $\mathrm{CaCl}_{2} \times 2 \mathrm{H}_{2} \mathrm{O}$ (117.6 mg/L), $\mathrm{MgSO}_{4} \mathrm{x}$ $7 \mathrm{H}_{2} \mathrm{O}(49.3 \mathrm{mg} / \mathrm{L}), \mathrm{NaHCO}_{3}(25.9 \mathrm{mg} / \mathrm{L})$ and $\mathrm{KCl}(2.3 \mathrm{mg} / \mathrm{L})$ (Sigma Aldrich Co.) were added to deionized water. They were fed with commercial food twice by day.

\section{Determination of LC50}

D. rerio were deprived for $24 \mathrm{~h}$ with food before the experiment, since nanoemulsion could be adhered to food and faeces, this characteristic minimizes the fluctuations of the NPOH exposure [35]. NPOH was diluted on aqueous media $(25,35,50,125 \mu \mathrm{g} / \mathrm{L}$ of $\mathrm{NPOH}$, expressed as POH content), which was placed on $1 \mathrm{~L}$ beakers in order to determine LC50, the control group only contains the surfactants $(125 \mu \mathrm{g} / \mathrm{L})$ and the blank group (without NPOH nor surfactants. All the experiments were performed by triplicate and 15 animals were used for each exposure concentration. Animals were kept in contact with NPOH aqueous dispersion for $48 \mathrm{~h}$, being observed behaviour and mortality at this period.

\section{Evaluation of behavioural parameters after treatment with $\mathrm{NPOH}$}

Once the $D$. rerio were exposed to different levels of NPOH for 48h the behaviour were analyzed as follows:

a. Stage I: 1) increase swimming activity; 2) tail tremors.

b. Stage II: 1) Circular swimming movement; 2) loss of posture.

c. Stage III: 1) Loss of motility; 2) Animal deposition in the base of the beaker; 3) Death.

Three replicates of 15 individuals were used for each experiment. The animal behaviour was recorded by a human observer at times $0,3,6,12,24,27,30$ and 48 h.

\section{Assessment of mortality}

Mortality was continuously monitored and fishes were considered dead when opercular movements and response to mechanical stimulus were not detected. After the end of experiment, remaining animals were submitted to euthanasia in cold water $4 \mathrm{oC}$.

\section{Evaluation of histological parameters}

Organs (gills, liver and kidneys) were fixed in Bowin's solution for $24 \mathrm{~h}$. After this period, fins were removed and tails were sectioned from the anus to the posterior part of dorsal fin. Thus, material was decalcified in 7\% EDTA solution for $48 \mathrm{~h}$ and then embedded in paraffin (Inlab Co.). Material was stained with HE (Harris hematoxylin from Laborclin and eosin-Inlab Co.). Analysis of organs was performed using optical microscopy (Olympusmicronal BX41) and photographs were obtained using DCE5C USB 2.0 digital camera and Scanning Electron Microscopy (microscope Hitachi TM3030PLUS). 
They were classified according to their gravity and occurrence, allowing determination of Mean Assessment Values (MAV) described by Schwaiger et al. [36], and HAI (Histological Alteration Index) based on method described by Poleksic \& Mitrovic-Tutundzic [37]. Histopathological parameters are show in Tables 1-3.

Table 1: Histological alterations considered for analysis of gills of D. rerio exposed to different concentrations of $\mathrm{NPOH}$.

\begin{tabular}{|c|c|}
\hline Histological Alterations & Stage \\
\hline \multicolumn{2}{|l|}{ a) Hypertrophy and hyperplasia of respiratory tissue } \\
\hline Hypertrophy of epithelial cells & I \\
\hline Thinning of epithelium & I \\
\hline Displacement or lifting up of epithelial cells & I \\
\hline Epithelial rupture & II \\
\hline $\begin{array}{l}\text { Hyperplasia of epithelial cells at the basis of secondary } \\
\text { lamellae }\end{array}$ & I \\
\hline Hyperplasia of epithelial cells on secondary lamellae & I \\
\hline Fusion of secondary lamellae & I \\
\hline Complete fusion of some secondary lamellae & I \\
\hline Complete fusion of all secondary lamellae & II \\
\hline Cellular degeneration & II \\
\hline Epithelial leukocyte infiltration & I \\
\hline \multicolumn{2}{|l|}{ b) Alterations on mucous and chloride cells } \\
\hline Hypertrophy and/or hyperplasia of mucous cells & I \\
\hline Presence of mucous cells on secondary lamellae & I \\
\hline Hypertrophy and/or hyperplasia of chloride cells & I \\
\hline Presence of chloride cells on secondary lamellae & I \\
\hline \multicolumn{2}{|l|}{ c) Alterations on lamellar blood vessels } \\
\hline Dilatation of capillaries & I \\
\hline Capillary disarrangement & I \\
\hline Vascular congestion & I \\
\hline Rupture of capillaries with hemorrhage & I \\
\hline Lamellar aneurism & II \\
\hline \multicolumn{2}{|l|}{ d) Terminal stage } \\
\hline Fibrosis & III \\
\hline Necrosis & III \\
\hline \multicolumn{2}{|l|}{ e) Gills parasites } \\
\hline Presence of parasites & I \\
\hline
\end{tabular}

Stage considered for each alteration indicated in the second column according to Poleksic \& Mitrovic-Tutundzic [37].
Table 2: Histological alterations considered for analysis of liver of $D$. rerio exposed to different concentrations of $\mathrm{NPOH}$.

\begin{tabular}{|c|c|}
\hline Histological Alterations & Stage \\
\hline \multicolumn{2}{|l|}{ a) Alterations on hepatocytes } \\
\hline Hepatic cordon disarrangement & I \\
\hline Outline cell loss or atypia & I \\
\hline Outline nuclear loss or atypia & I \\
\hline Increase in cell volume & I \\
\hline Nuclear atrophy & II \\
\hline Intense cytoplasmic vacuolation & I \\
\hline Nuclear vacuolation & II \\
\hline Decrease in the relative frequency of nuclei & I \\
\hline Cytoplasmic degeneration & II \\
\hline Nuclear degeneration & II \\
\hline Cellular disruption & II \\
\hline Glycogen reduction & I \\
\hline Biliary stagnation & I \\
\hline \multicolumn{2}{|l|}{ b) Alterations on blood vessels } \\
\hline Increase in the relative frequency of blood vessels & I \\
\hline Hyperemia & II \\
\hline Disruption of blood vessels & II \\
\hline Increase on relative volume of blood vessels & I \\
\hline \multicolumn{2}{|l|}{ c) Alterations on biliary } \\
\hline Degeneration of the bile canaliculi & II \\
\hline \multicolumn{2}{|l|}{ d) Terminal stage } \\
\hline Necrosis & III \\
\hline
\end{tabular}

\section{Statistical Analysis}

Probit analysis was employed using the Software GraphPad Prism version 5.0 with 95\% confidence interval for LC50 determination. The results were expressed as mean \pm SD and the histopathologicals data were analyses using one way ANOVA followed by Tukey-Kramer test for comparison between treated and control group and results with $\mathrm{p}<0.05, \mathrm{p}<0.01$ and $\mathrm{p}<0.001$ were considered statistically significant.

\section{Results and Discussion}

Three nanoemulsions were obtained by preparing different blends of non-ionic surfactants (sorbitan monooleate and polysorbate 80 ) in order to achieve different values of HLB (7, 8 
and 9). Macroscopic observation indicated that all formulations presented translucent appearance and bluish reflect, in addition mean diameter below $200 \mathrm{~nm}$ measured using photon correlation spectroscopy. These characteristics are in accordance to the concept of nanoemulsions, kinetically dispersed systems of small droplets $(20-200 \mathrm{~nm})$ containing two immiscible liquids and often stabilized by one or more surfactants [38]. Moreover, they presented low Polydispersity index and almost monomodal size distribution. This high homogeneity of particle size is desirable for stable nanoformulations [39]. HLB is a semi empirical scale to classify surfactants based on its hydrophile/Lypophile nature [40]. Smaller droplet size and most stable system are achieved when required HLB (rHLB) value of oily phase coincides with HLB value of surfactant(s) used in the emulsification. So establish the accurate HLB of pharmaceutical oils is a critical step for the abstention of small droplet emulsions, including nanoemulsions [41]. Smallest droplet size was achieved with nanoemulsion at HLB 9, therefore suggesting that this is the rHLB value of POH. We chose the nanoemulsion constituted by $2.8 \%$ of sorbitan monooleate, $2.2 \%$ of polysorbate $80,5.0 \%$ of $\mathrm{POH}$ and $90.0 \%$ of water for acute toxicological evaluation. Size distribution with mean droplet size and Polydispersity index values of three $\mathrm{POH}$ based nanoemulsions are presented in Figure 1.

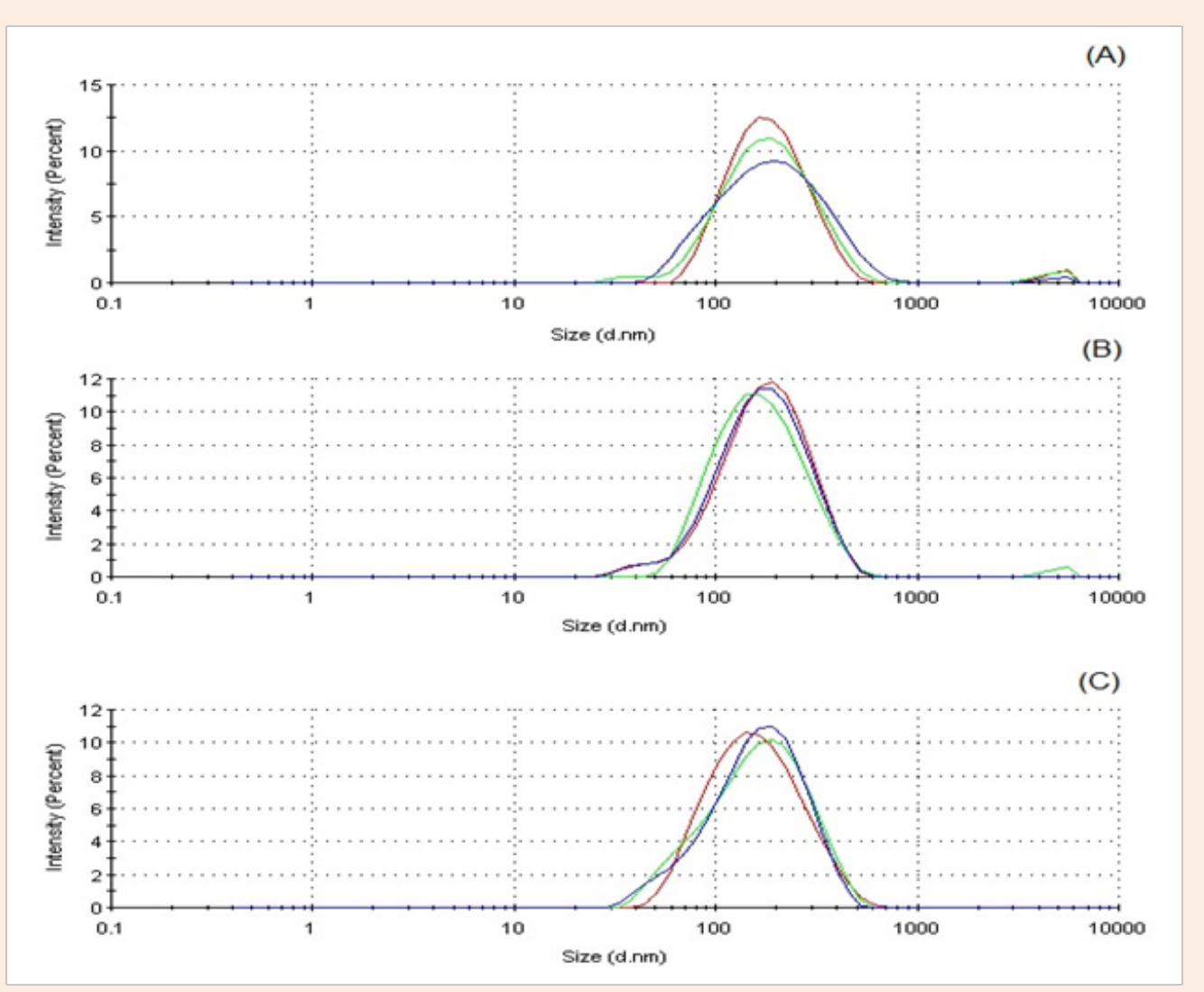

Figure 1: Size distribution for nanoemulsions prepared with POH. Mean droplet size at: HLB 7 (A): $164.8 \pm 1.3 \mathrm{~nm}$; HLB 8 (B): $149.7 \pm 1.1 \mathrm{~nm}$; HLB 9 (C): $136.7 \pm 0.5 \mathrm{~nm}$. Polydispersity index at: HLB 7 (A): $0.242 \pm 0.006$; HLB 8 (B): $0.215 \pm 0.011$; HLB 9 (C): $0.225 \pm 0.003$.

Exposure of $D$. rerio to different concentrations of $\mathrm{NPOH}$ induced several alterations, and they were classified according to stages I, II e III (Table 4). Ribeiro [42] expressed behavioural alterations of D. rerio according to stages I, II and III after exposure of these animals to ethanolic extract of Spilanthes acmella. It was observed that these alterations start with increasing excitability of the animal and culminates with loss of posture, animal deposition in the base of the beaker and death.

The behaviour of the animals was recorded every hour for two minutes. Toxic action of NPOH was relatively higher, being observed stress signals just after wards exposure. Higher concentration of $\mathrm{NPOH} \geq 50 \mu \mathrm{g} / \mathrm{L}$ induced following signals: increase swimming activity, followed by loss of posture, loss of motility, superficial respiration and animal deposition in the base of the beaker, until opercular movements were not observed indicating death (4 minutes after exposure).

At exposure concentrations of $25 \mu \mathrm{g} / \mathrm{L}$ and $35 \mu \mathrm{g} / \mathrm{L}$ of NPOH, the alterations were related to stages II and III. After $33 \mathrm{~h}$ of exposure, it was not observed behavioural alterations on animals exposed to $25 \mu \mathrm{g} / \mathrm{L}$ of NPOH. No behavioural alterations were observed for animals exposed to $125 \mu \mathrm{g} / \mathrm{L}$ of surfactants (HLB 9).

Swimming activity is among the behavioural changes the most important, because it is an indicator that integrates the 
internal status of the animal [43]. According Schreck et al. [44] the exposure of fish to a stressful situation, carries in his first defence mechanism, which most often, is the escape behaviour in an attempt to decrease the likelihood of death, or can occur a behaviour economy metabolic cost to maintain physiological homeostasis.

Table 3: Histological alterations considered for analysis of kidneys of $D$. rerio exposed to different concentrations of $\mathrm{NPOH}$.

\begin{tabular}{|c|c|}
\hline Histological Alterations & Stage \\
\hline \multicolumn{2}{|l|}{ a) Alterations on lymphoid tissue } \\
\hline Loss of cellular outline or atypical cellular outline & I \\
\hline \multicolumn{2}{|l|}{ b) Alterations on glomerulus and renal tubules } \\
\hline Low degeneration of tubular hyaline & I \\
\hline Severe degeneration on tubular hyaline & II \\
\hline Hypertrophy of tubular cells & I \\
\hline Tubular disorganization & I \\
\hline Glomerular disorganization & I \\
\hline Tubular degeneration & II \\
\hline Glomerular degeneration & II \\
\hline Increase on Bowman's capsule space & I \\
\hline Decrease on Bowman's capsule space & I \\
\hline Dilatation of glomerular capillaries & I \\
\hline Cytoplasmic degeneration of tubular cells & II \\
\hline Nuclear degeneration of tubular cells & II \\
\hline Presence of regenerated tubules or "new" nephrons & I \\
\hline $\begin{array}{c}\text { Presence of several granules PAS positive on tubular } \\
\text { epithelium }\end{array}$ & I \\
\hline Tubular obstruction & I \\
\hline Increase in tubular lumen & I \\
\hline Presence of lymphoid tissue on Bowman's capsule & II \\
\hline Decrease in the relative frequency of glomerulus & I \\
\hline \multicolumn{2}{|l|}{ c) Alterations on blood vessels } \\
\hline Dilation of blood vessels & I \\
\hline Hyperemia & II \\
\hline Rupture of blood vessels & II \\
\hline \multicolumn{2}{|l|}{ d) Terminal stage } \\
\hline Necrosis & III \\
\hline
\end{tabular}

Stage considered for each alteration is indicated in the second column according to Rigolin-Sá [47] and Takashima \& Hibiya [52].
Table 5 shows percentage of death animals after exposure to different concentrations of $\mathrm{NPOH}$. These results indicate increasing susceptibility of $D$. rerio to different concentrations, being observed that $100 \%$ of mortality was achieved at higher concentrations (>50 $\mathrm{\mu g} / \mathrm{L}$ ). According to Bilberg et al. [45] increasing concentrations of nanoformulations induce higher mortality levels. No mortality was observed in the group treated with $125 \mu \mathrm{g} / \mathrm{L}$ of surfactants, indicating the lethal effects were induced by $\mathrm{POH}$ nanoemulsified.

Plotting exposure concentrations $(25,35$ and $50 \mu \mathrm{g} / \mathrm{L})$ versus mortality levels it was possible to determine lethal concentration (CL50-48hs) at $34.3 \mu \mathrm{g} / \mathrm{L}$. Concentrations of 50 and $125 \mu \mathrm{g} / \mathrm{L}$ induced $100 \%$ of mortality. Chae et al. [46] evaluated toxicity induced by silver nanoparticles during $96 \mathrm{~h}$ and found LC50 value of $34.6 \mu \mathrm{g} / \mathrm{L}$, being similar to value found in the present study for NPOH (Figure 2). D. rerio has four branchial, as described for teleost fish, each containing two filament rows that have secondary lamellae. Figure 3 shows normal gill filament of D. rerio. Gills are characterized as potential absorption sites for substances in aqueous media, due to high surface area, small diffusion distance and high counter-current flow between water and blood [2].

Most frequent alterations on gills of $D$. rerio are presented in Table 6. First stage alterations were as follow: hypertrophy of epithelial cells (Figure 3) hyperplasia of epithelial cells (Figure 3), chloride cells on secondary lamellae and dilatation of capillaries. Rigolin-Sá [47] reported that hypertrophy of respiratory epithelium, hyperplasia and other alterations are gill defence mechanisms, promoting increase of water and blood barrier, which reduces and even prevents water flow between secondary lamellae. Further loss of respiratory surface or fusion of lamellae may induce mortality of the animals $[1,48]$. Partial fusion of secondary lamellae will occur if hyperplasia be restricted at the basis ou portion of lamellae, as it was observed with frequency at concentrations of 35 and $50 \mu \mathrm{g} / \mathrm{L}$ of NPOH. However, if hyperplasia occurs through the filaments, total fusion will be observed, considering that hyperplasic cells will fill all interlamellar space. In extreme cases of hyperplasia the lamellae fusion can occur across the gill filament, a situation not observed in any of exposure concentrations [49].

Total displacement of epithelium on secondary lamellae was observed with greater intensity on animals exposed to concentrations of 25, 35 and $50 \mu \mathrm{g} / \mathrm{L}$ of NPOH (Figures $3 \& 4$ ), being considered one of former alterations observed on gills of fishes exposed to toxic agents [50-52]. According to Meletti [49] mucous cells and chloride cells may become hyperplasic and/or hypertrophic due to toxic agents in water. Presence of chloride cells and mucous cells on fishes exposed to NPOH and surfactants occurred in all groups. However, smaller proportion of this alteration was observed on group treated with $125 \mu \mathrm{g} / \mathrm{L}$ of surfactant (Table 6).

Dilatation of capillaries on secondary lamellae was often accompanied by vascular congestion, characterized by blood stagnation. This alteration is rarely observed in normal conditions and the presence of several erythrocytes may cause aneurism or haemorrhage due to epithelial rupture and extravasations of 
blood [49]. Presence of aneurism was observed more frequently at $35 \mu \mathrm{g} / \mathrm{L}$ of NPOH. On the present study, it was also observed regressive alterations, induced by hypo function of cells and tissues, involving degeneration and necrosis. According to
Takashima \& Hibiya [52] several pathological agents may cause epithelial edema, vacuolation and necrosis on secondary lamellae. Impairment on blood flow observed for bronchial tissue affects gills function of gas exchange [49].

Table 4: Behavioral alterations after treatment with different concentrations of $\mathrm{POH}$ and control group on D. rerio at different observation time.

\begin{tabular}{|c|c|c|c|c|c|c|}
\hline & Time & $\begin{array}{c}25 \mu \mathrm{g} / \mathrm{L} \text { of } \\
\mathrm{NPOH}\end{array}$ & $\begin{array}{c}35 \mu \mathrm{g} / \mathrm{L} \text { of } \\
\mathrm{NPOH}\end{array}$ & $50 \mu \mathrm{g} / \mathrm{L}$ of NPOH & $125 \mu \mathrm{g} / \mathrm{L}$ of $\mathrm{NPOH}$ & $125 \mu \mathrm{g} / \mathrm{L}$ of Surfactants \\
\hline Stage I & $0^{\prime}$ & 1 and 2 & 1 & 1 and 2 & 1 and 2 & 1 \\
\hline Stage II & $0^{\prime}$ & 2 & 2 & 1 and 2 & 1 and 2 & \\
\hline Stage III & $0^{\prime}$ & 1 and 2 & 1 and 2 & 1 and 2 & 1,2 and 3 & \\
\hline Stage I & $3 \mathrm{~h}$ & 2 & & & & \\
\hline Stage II & $3 \mathrm{~h}$ & 2 & 2 & 2 & & \\
\hline Stage III & $3 \mathrm{~h}$ & 1 and 2 & 1 and 2 & 1,2 and 3 & & \\
\hline Stage I & $9 \mathrm{~h}$ & & & & & \\
\hline Stage II & $9 \mathrm{~h}$ & 2 & 2 & & & \\
\hline Stage III & $9 \mathrm{~h}$ & 1 and 2 & 1 and 2 & & & \\
\hline Stage I & $24 \mathrm{~h}$ & & & & & \\
\hline Stage II & $24 \mathrm{~h}$ & 1 and 2 & 2 & & & \\
\hline Stage III & $24 \mathrm{~h}$ & 3 & 1 and 2 & & & \\
\hline Stage I & $27 \mathrm{~h}$ & & & & & \\
\hline Stage II & $27 \mathrm{~h}$ & 2 & 2 & & & \\
\hline Stage III & $27 \mathrm{~h}$ & 2 & 1 and 2 & & & \\
\hline Stage I & $33 \mathrm{~h}$ & & & & & \\
\hline Stage II & $33 \mathrm{~h}$ & & 2 & & & \\
\hline Stage III & $33 \mathrm{~h}$ & & 1,2 and 3 & & & \\
\hline Stage I & $48 \mathrm{~h}$ & & & & & \\
\hline Stage II & $48 \mathrm{~h}$ & & 2 & & & \\
\hline Stage III & $48 \mathrm{~h}$ & & 1,2 and 3 & & & \\
\hline
\end{tabular}

Stage I: 1) increase swimming activity, 2) tail tremors; Stage II: 1) Circular swimming movement, 2) loss of posture; Stage III: 1) Loss of motility; 2) Animal deposition in the base of the beaker, 3) Death.

Table 5: Number and percentage of dead animals after treatments with different concentrations of NPOH on D. rerio ( $\mathrm{n}=15$ animals/group).

\begin{tabular}{|c|c|c|c|c|c|c|}
\hline Concentration & $\mathbf{0 , 0} \boldsymbol{\mu g} / \mathbf{L}$ & $\mathbf{2 5} \boldsymbol{\mu g} / \mathbf{L}$ & $\mathbf{3 5} \boldsymbol{\mu g} / \mathbf{L}$ & $\mathbf{5 0} \boldsymbol{\mu g} / \mathbf{L}$ & $\mathbf{1 2 5} \boldsymbol{\mu g} / \mathbf{L}$ & $\mathbf{1 2 5} \boldsymbol{\mu g} / \mathbf{L}$ of Surfactants \\
\hline Number of death animals & 0 & 1 & 8 & 15 & 15 & 0 \\
\hline Percentage & $0 \%$ & $6 \%$ & $53 \%$ & $100 \%$ & $100 \%$ & $0 \%$ \\
\hline
\end{tabular}

Table 6: Mean of Histological Alteration Index (HAI) of D. rerio gills after exposure do different concentrations of NPOH in triplicate (n=15 animals/ group).

\begin{tabular}{|c|c|c|c|c|c|c|}
\hline Replicate & Blank & $\mathbf{1 2 5} \boldsymbol{\mu g} / \mathbf{L}$ of Surfactants & $\mathbf{2 5} \boldsymbol{\mu g} / \mathbf{L ~ o f ~} \mathbf{~ P O H}$ & $\mathbf{3 5} \boldsymbol{\mu g} / \mathbf{L ~ o f ~ N P O H}$ & $\mathbf{5 0} \boldsymbol{\mu g} / \mathbf{L ~ o f ~} \mathbf{~ N O H}$ & $\mathbf{1 2 5} \boldsymbol{\mu g} / \mathbf{L} \mathbf{~ o f ~ N P O H}$ \\
\hline 1 & 0 & 8.8 & 53.8 & 44.6 & 28.4 & 10.9 \\
\hline 2 & 0 & 4.6 & 54.2 & 30.8 & 28.6 & 20.6 \\
\hline 3 & 0 & 4 & 54.2 & 26.6 & 28.8 & 19.4 \\
\hline Mean \pm SD & $0.0 \pm 0.0$ & $5.8 \pm 1.51$ & $54 \pm 3.05$ & $34,6 \pm 0.11$ & $28.6 \pm 5.43$ & $16.9 \pm 0.13$ \\
\hline
\end{tabular}




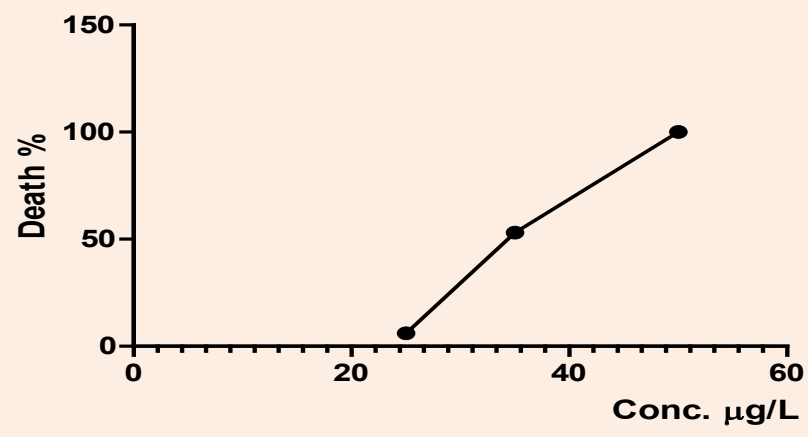

Figure 2: Effects of administration of differents NPOH concentrations $(25 \mu \mathrm{g} / \mathrm{L}, 35 \mu \mathrm{g} / \mathrm{L}, 50 \mu \mathrm{g} / \mathrm{L}$ and $125 \mu \mathrm{g} / \mathrm{L})$ on zebrafish. $\mathrm{n}=15$ animals $/$ group, $\mathrm{LC}_{50(48 \mathrm{~h})}=34.3 \mu \mathrm{g} / \mathrm{L}$.
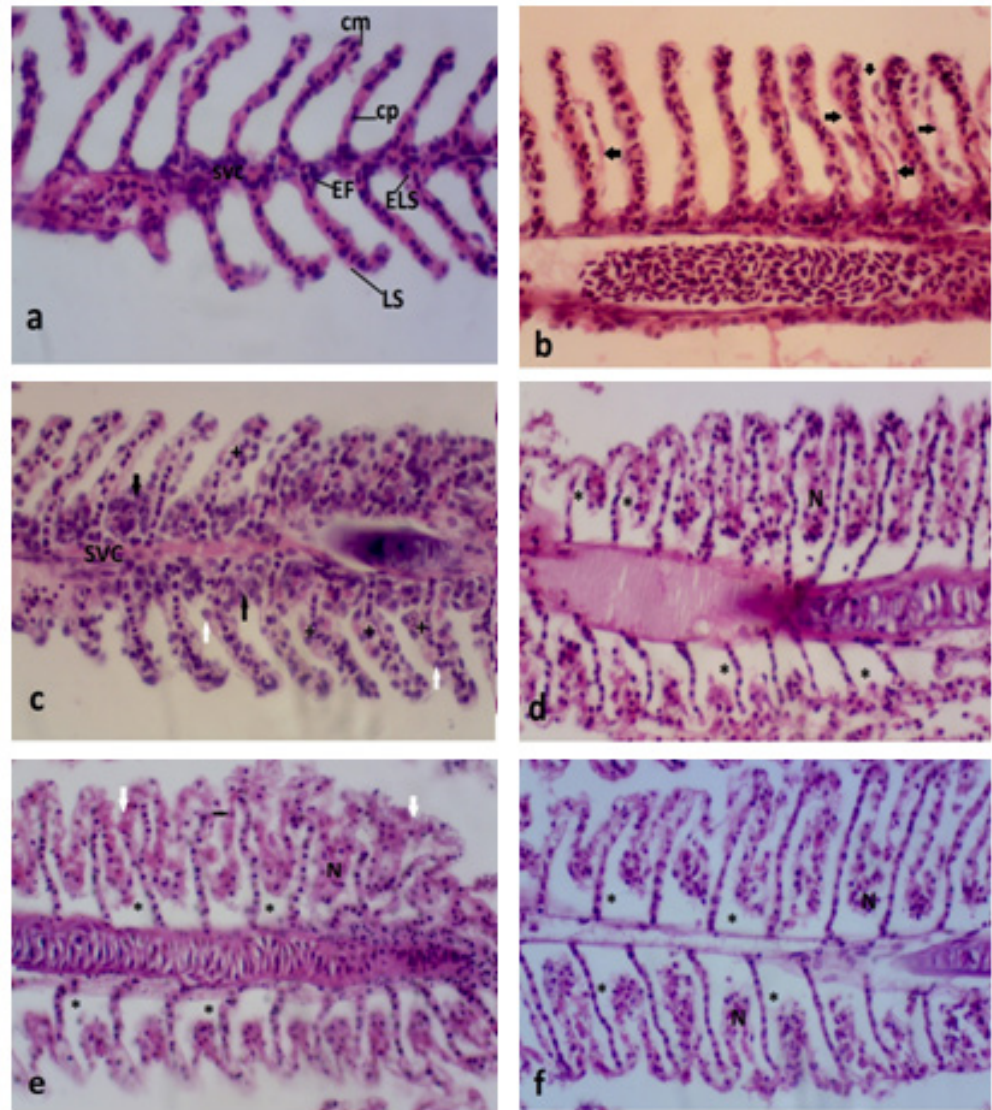

Figure 3: a) Normal gill filament on longitudinal histological sectionof D. rerio. cm-marginal channel; cp-pillar cells; EF- filament stratified epithelium; ELS - secondary lamellar squamous epithelium; LS -secondary lamelae, SVC-central venous sinus; b) Gill filament on longitudinal section of $D$. rerio exposed to $125 \mu \mathrm{g} /$ Lof surfactants. Detachment of lamellar respiratory epithelium (indicated by arrows); c) Gill filament on longitudinal section of $D$. rerio exposed to $125 \mu \mathrm{g} / \mathrm{L}$ of NPOH. Hypertrophy of epithelial cells (+), hyperplasia of epithelial cells at the basis of secondary lamellae (black arrows) and presence of chloride cells (white arrows). Detail of central venous sinus (SVC); d) Gill filament on longitudinal section of $D$. rerio exposed to $50 \mu \mathrm{g} / \mathrm{L}$ of $\mathrm{NPOH}$. Displacement of respiratory epithelium $\left(^{*}\right)$ and necrosis of respiratory epithelial cells (N); e) Gill filament on longitudinal section of $D$. rerio exposed to $35 \mu \mathrm{g} / \mathrm{L}$ of NPOH. Displacement of lamellar epithelium cells $(*)$, Mucus secretion (white arrows), degeneration of lamellar epithelium cells (black arrows) and necrosis (N); f) Gill filament on longitudinal section of D. rerio exposed to $25 \mu \mathrm{g} / \mathrm{L}$ of NPOH. Total displacement of respiratory epithelium $\left({ }^{*}\right)$ and necrosis of respiratory epithelium cells (N). (HE, $\left.5 \mu \mathrm{m}\right)$. 

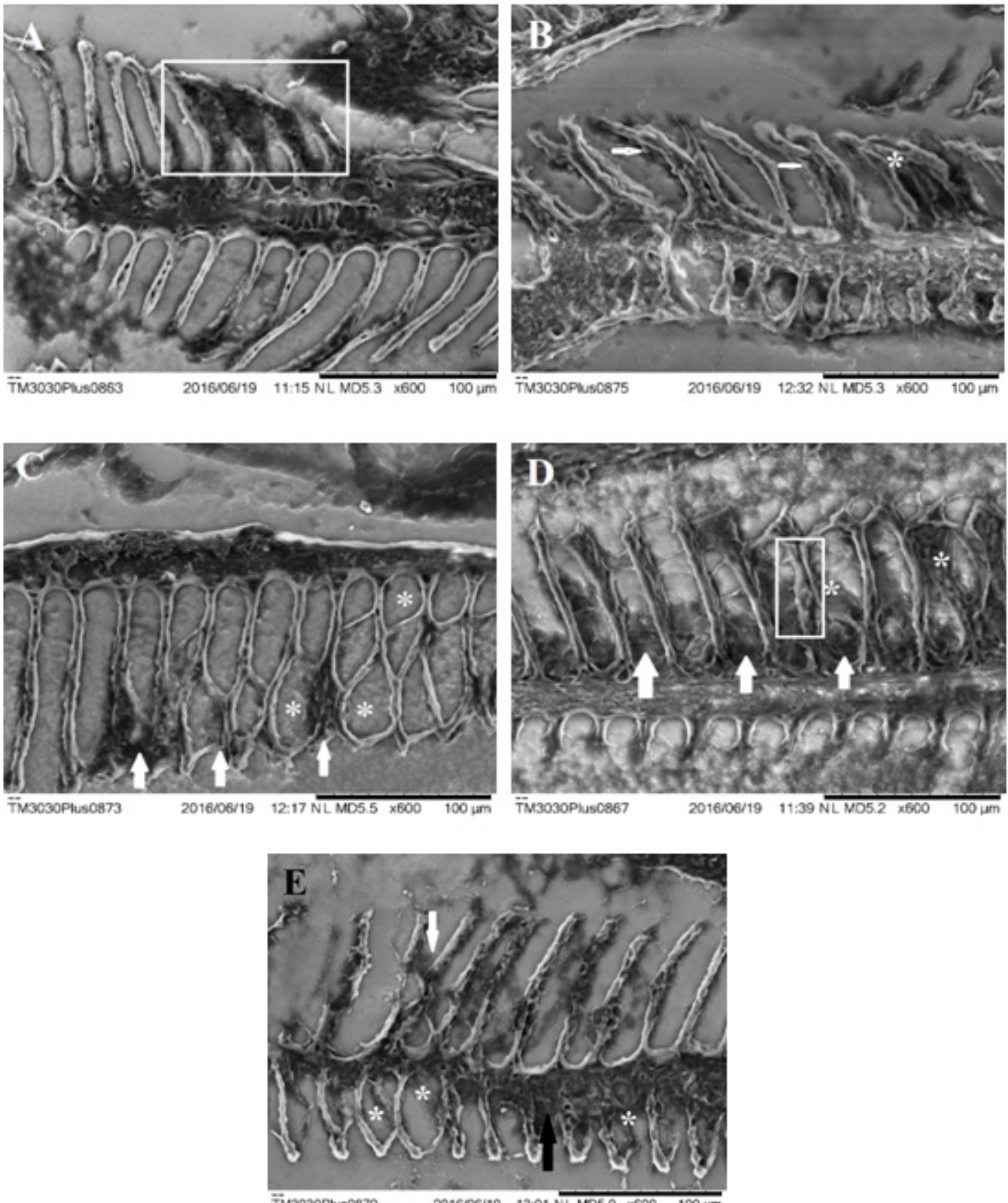

Figure 4: Scanning electron microscopy of the gills of Danio rerio (zebrafish). A) Filament Branchial of Danio rerio exposed to concentration of $125 \mu \mathrm{g} / \mathrm{L}$ of surfactant. Observe hypertrophy of the epithelial cells (white marked area). B) Gill filament of Danio rerio exposed to concentration of $125 \mu \mathrm{g} / \mathrm{L}$ of NPOH. Note the presence of chloride cells (white arrows) and hyperplasia along some secondary lamellae (asterisk). C) Gill filament of Danio rerio exposed to concentration of $50 \mu \mathrm{g} / \mathrm{L}$ of $\mathrm{NPOH}$. Observe displacement and elevation of the epithelium of secondary lamellae (asterisk) and hyperplasia at the top of some secondary lamellae (white arrows). D) Gill filament of Danio rerio exposed to concentration of $35 \mu \mathrm{g} / \mathrm{L}$ of NPOH. Observe vascular congestion (marked area), displacement and elevation of the epithelium of secondary lamellae (asterisk) and hyperplasia because of secondary lamellae. E) Gill of Danio rerio filament exposed to concentration of $25 \mu \mathrm{g} / \mathrm{L}$ of NPOH. Note hyperplasia some secondary lamellae (white arrows) the epithelium displacement and elevation of the secondary lamellae (asterisk) by hyperplasia and secondary lamellae. 
Tables 6 \& 7, Figures 3 \& 4 shows that NPOH at 25, 35 and 50 $\mu \mathrm{g} / \mathrm{mL}$ (Figure 4) induced significative alterations on gills of D. rerio, when compared with the control (surfactants, $125 \mu \mathrm{g} / \mathrm{L}$ ). Considering HAI values, it was possible to observe that NPOH at $25 \mu \mathrm{g} / \mathrm{L}$ caused more damage to gill tissue $(\mathrm{p}<0.05$ and $\mathrm{p}<0.001)$ when compared to other treatments (Figure 4), followed by concentration of $35 \mu \mathrm{g} / \mathrm{L}(\mathrm{p}<0.001)$ (Figure 4). On this context, it is possible to observe that low concentrations of NPOH presented higher HAI values, since exposure time was higher than those observed for the concentrations above of $>50 \mu \mathrm{g} / \mathrm{L}$. These results are in harmony with previous data obtained by Federici et al. [52] which indicated that significative alterations were observed on gill tissue of Oncorhynchus mykiss after treatment with titanium dioxide nanoparticles.

Table 7: Occurrence of alterations in percentage on gills of treated groups exposed to different concentrations of NPOH.

\begin{tabular}{|c|c|c|c|c|c|c|}
\hline Alterations & Stage & $125 \mu \mathrm{g} / \mathrm{L}$ of Surfactants & $25 \mu \mathrm{g} / \mathrm{L} \mathrm{of} \mathrm{NPOH}$ & $35 \mu \mathrm{g} / \mathrm{L}$ of $\mathrm{NPOH}$ & $50 \mu \mathrm{g} / \mathrm{L}$ of $\mathrm{NPOH}$ & $125 \mu \mathrm{g} / \mathrm{L}$ of NPOH \\
\hline HTEC & $\mathrm{I}$ & 86.6 & 100 & 100 & 100 & 100 \\
\hline TEpi & I & 6.6 & 0 & 0 & 0 & 0 \\
\hline $\operatorname{DEC}(\mathrm{LS})$ & $\mathrm{I}$ & 80 & 100 & 100 & 93.3 & 40 \\
\hline HECBSL & I & 73.3 & 80 & 100 & 93.3 & 100 \\
\hline HECSL & $\mathrm{I}$ & 13.3 & 53.3 & 33.3 & 40 & 33.3 \\
\hline FPLS & I & 33,3 & 80 & 93.3 & 93.3 & 33.3 \\
\hline LeuELS & I & 0 & 0 & 6.6 & 6,6 & 0 \\
\hline HP/HTCM & I & 6.6 & 80 & 93.3 & 86.6 & 60 \\
\hline HP/HTCC & I & 20 & 93.3 & 100 & 93.3 & 86.6 \\
\hline CCSL & I & 66.6 & 93.3 & 100 & 93.3 & 86.6 \\
\hline MuLS & I & 66.6 & 93.3 & 93.3 & 86.6 & 73.3 \\
\hline $\mathrm{DiC}$ & I & 66.6 & 93.3 & 93.3 & 93.3 & 93.3 \\
\hline $\mathrm{CDe}$ & I & 80 & 93.3 & 93.3 & 93.3 & 93.3 \\
\hline VC & I & 73.3 & 100 & 80 & 80 & 6.6 \\
\hline Par & I & 0 & 0 & 0 & 0 & 0 \\
\hline CFSSL & I & 20 & 53.3 & 46.6 & 26.6 & 13.3 \\
\hline CFALSL & II & 0 & 0 & 0 & 0 & 0 \\
\hline $\mathrm{CD}$ & II & 0 & 100 & 86.6 & 80 & 0 \\
\hline ER & II & 20 & 80 & 73.3 & 60 & 20 \\
\hline Hem & II & 0 & 0 & 6.6 & 0 & 0 \\
\hline $\mathrm{Na}$ & II & 6.6 & 33.3 & 4 & 33.3 & 0 \\
\hline Fib & III & 0 & 0 & 0 & 0 & 0 \\
\hline $\mathrm{Nec}$ & III & 0 & 100 & 93.3 & 93.3 & 20 \\
\hline
\end{tabular}

Only group treated with surfactants $(125 \mu \mathrm{g} / \mathrm{L})$ presented organ functionally normal without any alteration (Stage I). NPOH at 125 $\mu \mathrm{g} / \mathrm{L}$ induced low and moderate alterations (Stage II) and $\mathrm{NPOH}$ at 25,35 and $50 \mu \mathrm{g} / \mathrm{L}$ induced moderate and severe alterations, widely distributed through organs (Stage III). Statistically significant difference, when compared to control group, may be attributed to exposure time to each $\mathrm{NPOH}$ concentration. Thus, higher toxicity observed to lower concentrations $(<35 \mu \mathrm{g} / \mathrm{L})$ may be due to the fact that most of fishes survived until the end of the experiment (48h). Several studies have shown that nanoscale materials may induce toxic effects on gills of D. rerio, mainly due to small size of particles that which is directly related to morphological alterations due to enhanced absorption [53-57].

Liver of $D$. rerio has typical vertebrate hepatocytes. Table 8 shows alterations on liver of fishes exposed to NPOH. Most frequent stage I alterations were hepatic cord on disarrangement; outline cells loss or atypical, cytoplasm vacuolation (Figure 5) and glycogen reduction (Figure 5). According to Meletti [49] cytoplasmic vacuolation on hepatocytes may be an indirect measurement of glycogen or lipid content at the cells. Rigolin-Sá [47] reported that vacuolation might be due to the reduction of glycogen content on liver and increase amount of lipids, which may combine with toxic agents and accumulate on hepatocytes.

Biliary stagnation was observed in higher proportion on groups treated with $\mathrm{NPOH}$. Stagnated bile appear as yellowbrownish granules or green-brownish granules inside the cells $[52,58]$. This alteration is called cholestasis and it is characterized as a pathophysiological condition attributed to metabolism failure of biliary pigments excretion. It is necessary that bilirubin become solubilised in water in order to be excreted and it involves conjugation to glucuronic acid. Thus, if bilirubin ability to bind to this acid decreases this hepatic dysfunction may occur [58]. 


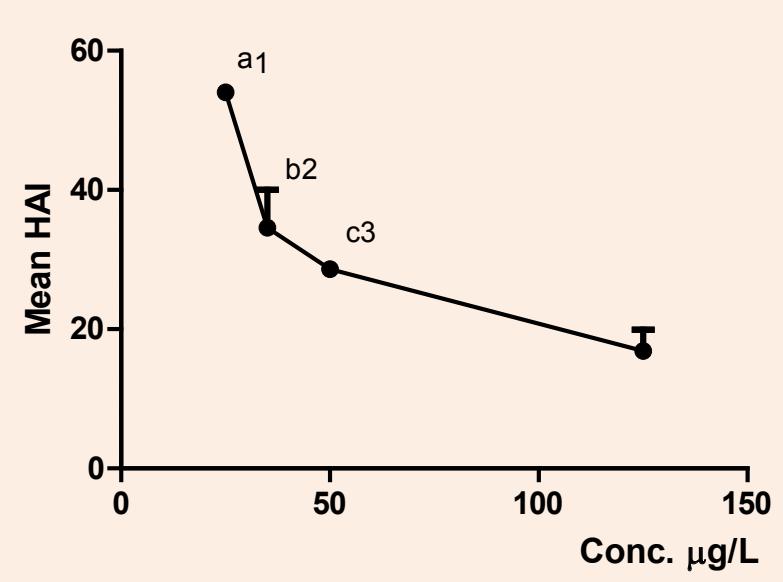

Figure 5: Mean HAI obtained from alterations observed on D. rerio gills exposed to NPOH $(25,35,50$ and $125 \mu \mathrm{g} / \mathrm{L})$. Each point represents mean $\pm \mathrm{SD}(\mathrm{n}=15$ animals/group). Anova followed by Tukey-Kramer test, $\mathrm{a}=\mathrm{p}<0.001, \mathrm{~b}=\mathrm{p}<0.001$ and $\mathrm{c}=\mathrm{p}<0.01$ compared to control group (surfactants at $125 \mu \mathrm{g} / \mathrm{L}$ ); $1=\mathrm{p}<0.05$ comparing $25 \mu \mathrm{g} / \mathrm{L}$ to $50 \mu \mathrm{g} / \mathrm{L}$ and $\mathrm{p}<0.001$ comparing $25 \mu \mathrm{g} / \mathrm{L}$ to $125 \mu \mathrm{g} / \mathrm{L} ; 2=\mathrm{p}<0.001$ comparing $35 \mu \mathrm{g} / \mathrm{L}$ to $125 \mu \mathrm{g} / \mathrm{L}$ and $3=\mathrm{p}<0.01$ comparing $50 \mu \mathrm{g} / \mathrm{L}$ to $125 \mu \mathrm{g} / \mathrm{L}$.

Hyperemia (Figure 5), cytoplasmic degeneration and nuclear degeneration (Figure 5) were more frequent Stage II alterations, being observed after exposure to $\mathrm{NPOH}$ at 50,35 and $25 \mu \mathrm{g} / \mathrm{L}$ (Figure 6). Takashima \& Hibyia [52] suggested that depth studies are need to elucidate if high cytoplasmic vacuolation on liver of $D$. rerio constitutes a negative histological alteration or if this event should be considered an alteration associated to some degeneration. Nuclear degeneration and cellular disruption on hepatocytes shows high hepatotoxicity of NPOH.

Regarding stage III alterations, only groups treated with NPOH showed focal and total necrosis of hepatic tissue (Figure 5), while none of these alterations were observed on group treated with surfactants (125 $\mu \mathrm{g} / \mathrm{L}$ ) (Figure 5). According to Castro et al. [59] the toxic agents promote enhanced inflammatory response (infiltration of leukocytes) and necrosis areas. Poleksic \& Karan [60] observed necrosis on hepatocytes of carps and related the importance of histopathological studies to verify injury induced by toxic agents. Liver is considered the main organ for drug metabolization and exerts an important detoxification function. It bio transforms and eliminates many xenobiotics, mainly as conjugates, with no impairment. However, some of them are concentrated to toxic levels and other are bioactivated to intermediary reactive compounds that may injure liver $[61,62]$.

Tables $8 \& 9$, and Figures $6 \& 7$ shows that NPOH $(25,35$ e 50 $\mu \mathrm{g} / \mathrm{L})$ caused significant alterations on D. rerio, when compared to surfactants $(125 \mu \mathrm{g} / \mathrm{L})(\mathrm{p}<0.05, \mathrm{p}<0.01)$. No statistically significant difference was observed when compared to $125 \mu \mathrm{g} /$ $\mathrm{mL}$ da NPOH. According to Hudes et al. [63] and Azzoli et al. [64] no evidence of hepatic toxicity of $\mathrm{POH}$ was reported. This affirmative shows that NPOH is in accordance with toxicity standards observed for several tested nanoformulations $[45,57]$.

Normal functionally liver without histological alterations (Stage I) was observed only for group treated with surfactants $(125 \mu \mathrm{g} / \mathrm{L})$. Concentrations of NPOH $(25,35,50$ and $125 \mu \mathrm{g} / \mathrm{L})$ induced moderate to severe alterations. Klingelfus [65] observed significative histological alterations on liver of Rhamdia quelen after exposure to titanium dioxide (TiO2) and inorganic lead (PbII). Regarding most frequent stage I alterations (Table 10) on kidneys tissue of $D$. Rerio exposed to NPOH, special attention is given to tubular alterations on animals exposed to lower concentrations $(<50 \mu \mathrm{g} / \mathrm{L})$. It was also observed hypertrophy of tubular cells on these animals. According to Meletti [49] these alterations are classified as cloudy swelling type, being characterized by the presence of hypertrophy tubular epithelial cells with fine granules of eosinophils on cytoplasm. It was also observed hyaline degeneration, characterized by presence of great granules of eosinophils on cytoplasm. According to, Takashima \& Hibiya [52] and Hinton and Laurén [66] this alteration can be generated inside the cell or caused by reabsorption of an excess of proteic substances filtrated by glomerulus. Most of tubular alterations on kidneys of $D$. rerio are induced by metabolic disorders caused by toxic agents [49]. According to Takashima \& Hibiya [52] most of tubular alterations are found on epithelial cells and many of them are degenerative and culminate on necrosis. However, these authors relate that hypertrophy of tubular cells and hyaline degeneration may not always induce necrosis. On the present study, necrosis was classified as a stage III alteration and was observed on all NPOH and surfactant treated groups. It was also observed that necrosis was directly related to hypertrophy of tubular cells and hyaline degeneration (low and severe) (Table 11).

Dilatation of glomerular capillaries, glomerular degeneration, increase and decrease on Bowman's capsule space (Figures 7) were frequent in all NPOH and surfactants treated groups (Table 9). According to Takashima and Hibiya [52] this alteration occurs on pathological conditions due to basal lamina alterations, being often accompanied by alterations on podocytes and endothelial cells, such as hyperplasia. On this case, dilatation of glomerular capillaries occurs increasing its volume and consequently 
inducing decrease of Bowman's capsule space (Figure 8). In another cases, dilated capillaries may compress glomerulus, inducing hyperemia. All NPOH treated groups and, with less frequency, surfactant group, presented hyperemy. Decrease on Bowman's capsule space may affect blood filtration and all renal function. However, opposite effect may occur and Bowman's capsule space can increase. This alteration was less observed on groups treated with $\mathrm{NPOH}$ and surfactants, but maybe attributed to atrophy of glomerular degeneration (Figure 9). Meletti [49] also observed this type of alteration on kidneys of S. notomelas exposed to industrial sediments.
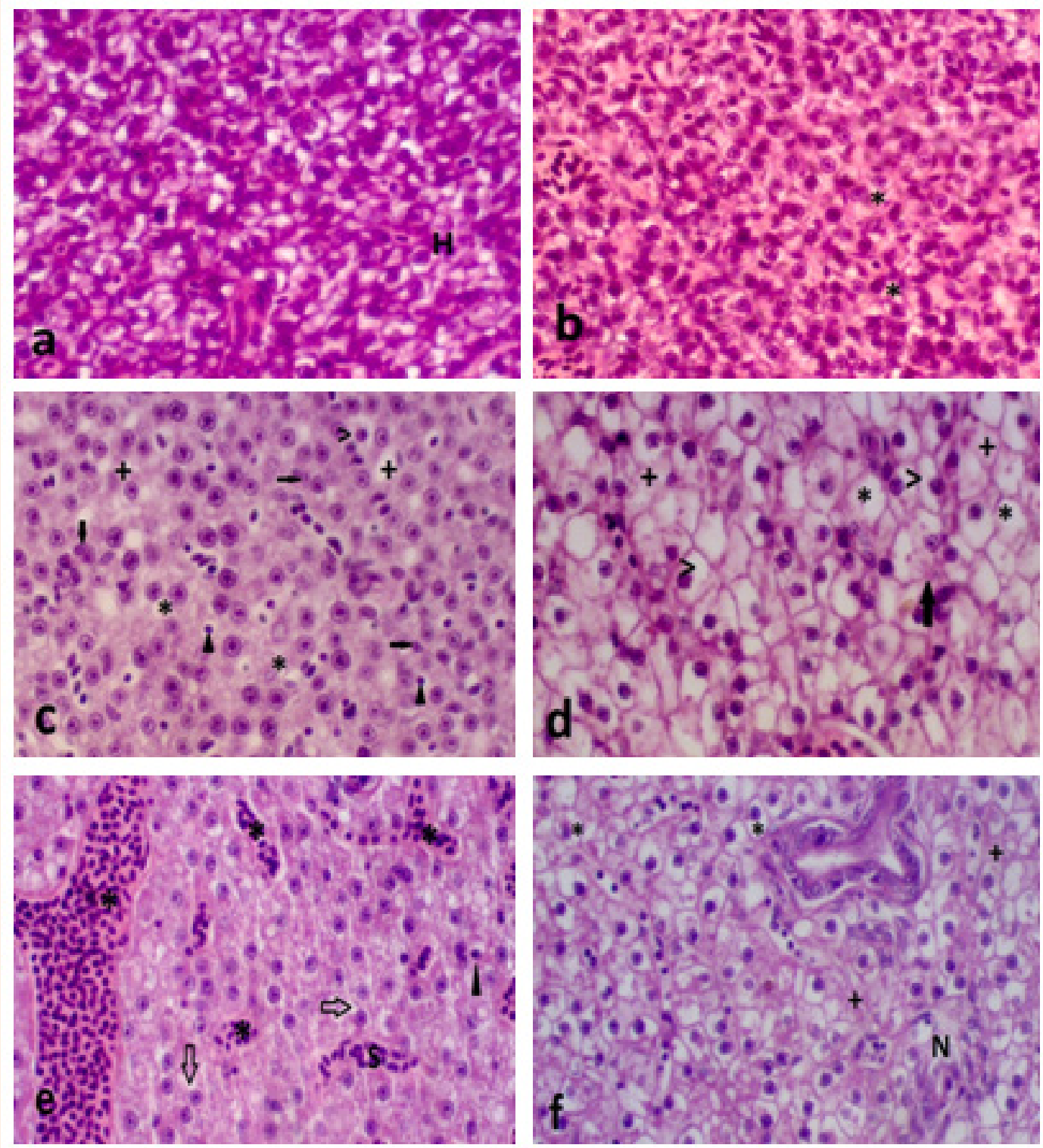

Figure 6: a) Normal liver on longitudinal histological section of D. rerio. Hepatocytes (H); b) Liver on longitudinal section of $D$. rerio exposed to $125 \mu \mathrm{g} / \mathrm{mL}$ of surfactants. Cytoplasmic vacuolation ( ${ }^{*}$; c) Liver on longitudinal section of $D$. rerio exposed to $125 \mu \mathrm{g} / \mathrm{L}$ of NPOH. Cytoplasmic vacuolation (>), biliary stagnation $(\boldsymbol{\Lambda})$, nuclear degeneration (black arrows), cytoplasmic degeneration $(*)$ and glycogen reduction $(+)$; d) Liver on longitudinal section of $D$. rerio exposed to $50 \mu \mathrm{g} / \mathrm{L}$ of NPOH. Intense cytoplasmic vacuolation ( $>$ ), glycogen reduction ( + ), outline cell atypia (arrows) and decrease in the relative frequency of nuclei; e) Liver on longitudinal section of $D$. rerio exposed to $35 \mu \mathrm{g} / \mathrm{Lof}$ NPOH. Cytoplasmic degeneration (arrows), biliary stagnation $(\boldsymbol{\Delta})$, presence of sinusoids and intense presence of leukocytes $(*$ ) indicating hyperemia; f) Liver on longitudinal section of $D$. rerio exposed to $25 \mu \mathrm{g} / \mathrm{L}$ of NPOH. Intense cytoplasmic vacuolation $(*)$, cytoplasmic degeneration (+) and focal necrosis (N). (HE, $5 \mu \mathrm{m})$. 

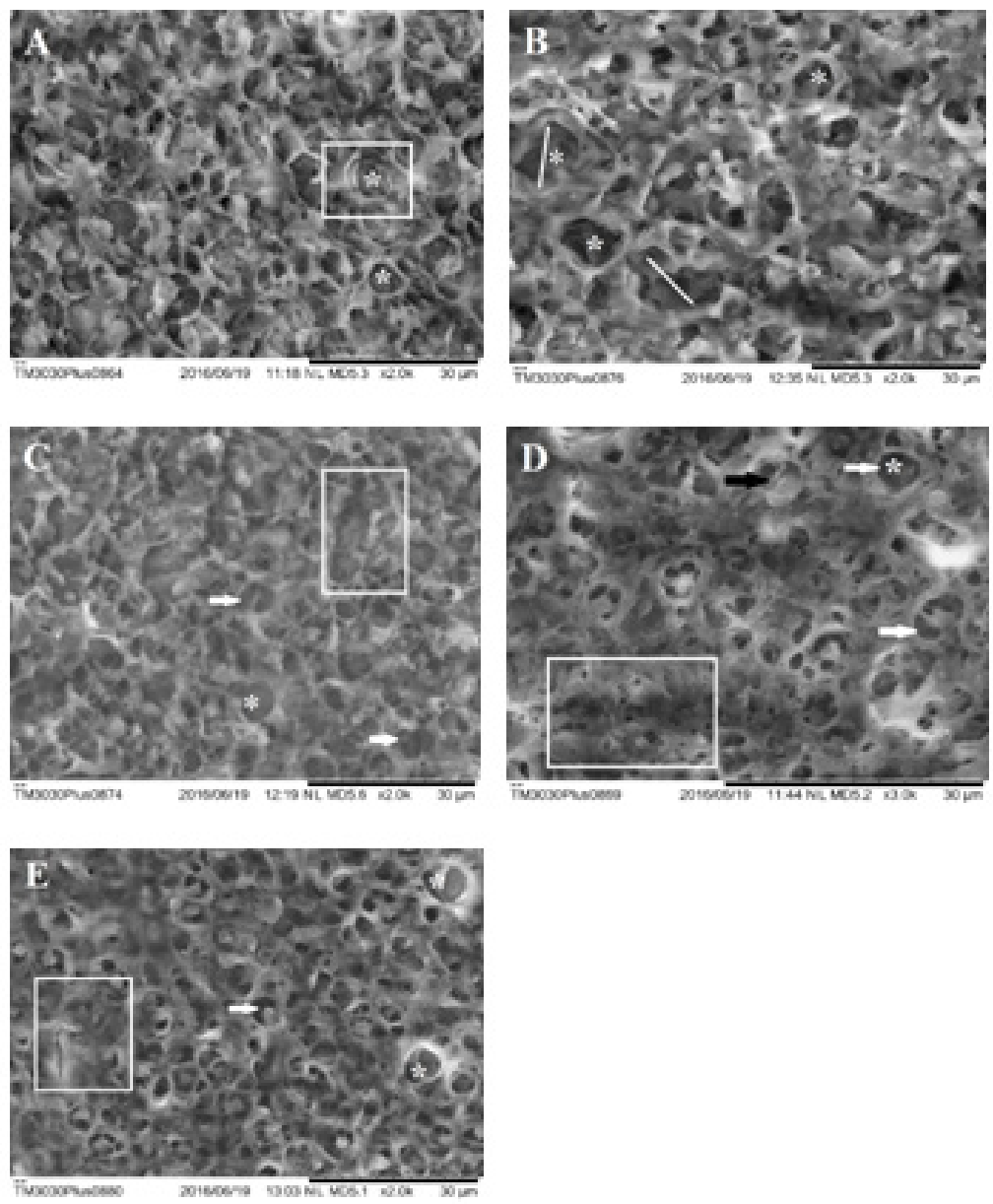

Figure 7: Scanning electron microscopy of liver of Danio rerio (zebrafish). A) Liver of Danio rerio exposed to the concentration of $125 \mu \mathrm{g} / \mathrm{L} \mathrm{surfactant.}$ Observe degeneration of the cytoplasm (white marked area) and vacuolization of the cytoplasm (asterisk). B) Liver of Danio rerio exposed to the concentration of $125 \mu \mathrm{g} / \mathrm{L}$ of NPOH. Observe cytoplasmic degeneration (bars) and intense vacuolation (asterisk). C) Liver of Danio rerio exposed to concentration of $50 \mathrm{\mu g} / \mathrm{L}$ of NPOH. Observe necrosis (marked area), vacuolation of the cytoplasm (asterisk) and decrease in relative frequency

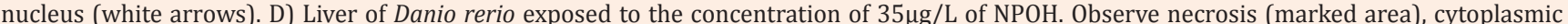
degeneration (black arrow) vacuolation (white arrow) and absence of nucleus (asterisk). E) Liver of Danio rerio exposed to concentration of 25 $\mu \mathrm{g} / \mathrm{L}$ of NPOH. Observe necrosis (marked area), vacuolation (white arrow) and absence of nucleus (asterisk).

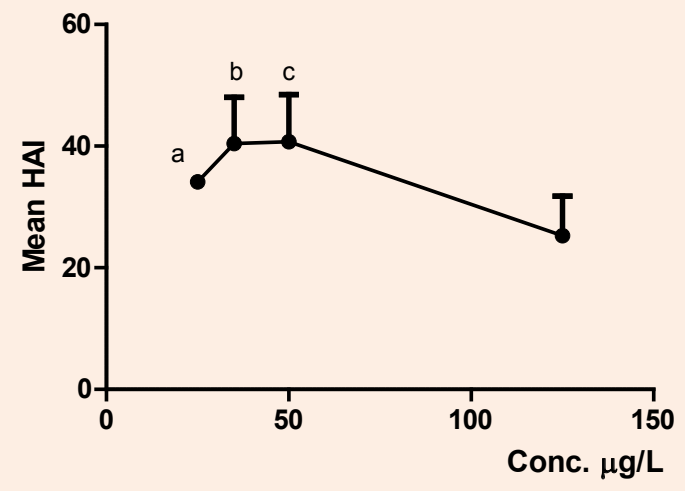

Figure 8: Mean HAI obtained from alterations observed on $D$. rerio liver exposed to NPOH $(25,35,50$ and $125 \mu \mathrm{g} / \mathrm{L})$. Each point represents mean \pm $\mathrm{SD}(\mathrm{n}=15$ animals/group). Anova followed by Tukey-Kramer test, $\mathrm{a}=\mathrm{p}<0.05, \mathrm{~b}=\mathrm{p}<0.01$ and $\mathrm{c}=\mathrm{p}<0.01$ compared to control group (surfactants at $125 \mu \mathrm{g} / \mathrm{L})$. 

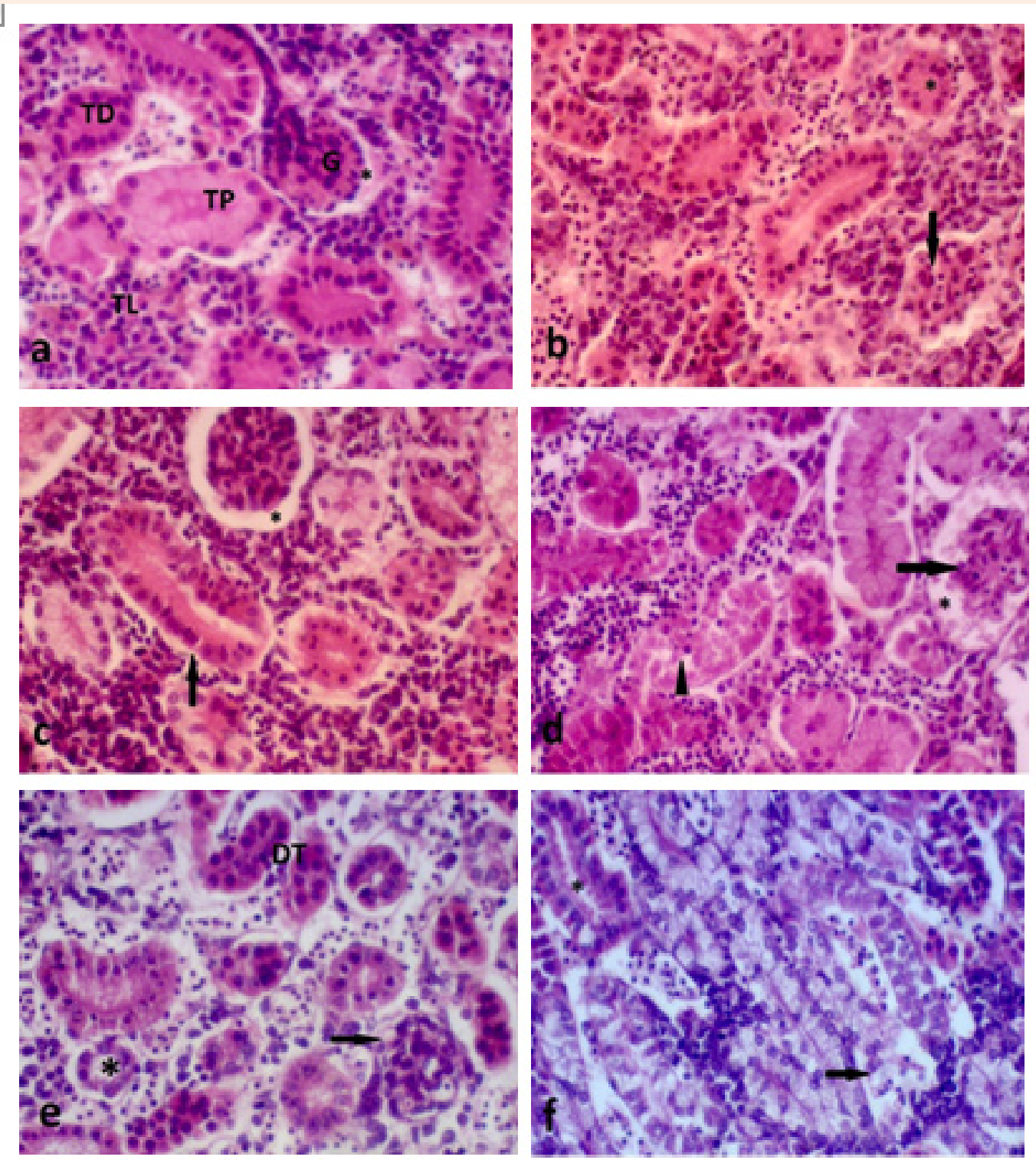

Figure 9: a) Normal kidney on longitudinal histological sectionofD. rerio. Glomerulus (G). Intercapsular space $(*)$. Lymphoid tissue (TL), distal tubule (TD), proximal tubule (TP); b) Kidney on longitudinal section of $D$. rerio exposed to $125 \mu \mathrm{g} / \mathrm{Lof}$ surfactants. Dilated glomerular capillaries (arrows) and tubular obstruction $\left({ }^{*}\right.$ ); c) Kidney on longitudinal section of D. rerio exposed to $125 \mu \mathrm{g} / \mathrm{L}$ of NPOH. Increase on Bowman's capsule space $\left({ }^{*}\right)$ and degeneration of hyaline tubular light (arrow); d) Kidney on longitudinal section of $D$. rerio exposed to $50 \mu \mathrm{g} / \mathrm{L}$ of NPOH. Increase on Bowman's capsule space $\left({ }^{*}\right)$ due to glomerular degeneration (arrow) and degeneration of tubular hyaline ( $\left.\boldsymbol{\Delta}\right)$; e) Kidney on longitudinal section of D. rerio exposed to $35 \mu \mathrm{g} / \mathrm{L}$ of NPOH. Decrease on Bowman's capsule space (arrow), increase in tubular lumen $(*$ ) and tubular disorganization (DT). f) Kidney on longitudinal section of $D$. rerio exposed to $25 \mu \mathrm{g} / \mathrm{Lof}$ NPOH. Tubular degeneration (arrow) and increase in tubular lumen. (HE, $5 \mu \mathrm{m}$ ).

Table 11 and Figures $10 \& 11$ shows that NPOH $(25,35$ and $50 \mu \mathrm{g} / \mathrm{L}$ ) did not cause significative alterations on kidneys of D. rerio. This result may be associated to different exposure times, since fishes exposed to higher concentrations of NPOH $(\geq 50$ $\mu \mathrm{g} / \mathrm{L}$ ) died in the first $3 \mathrm{~h}$ (Table 4 ) and not sufficient time to metabolization of NPOH on kidneys, differing from groups treated with other concentrations $(<35 \mu \mathrm{g} / \mathrm{L})$ that survived until de end of experiment (48h). Srivastava \& Gupta [67] also reported similar histological alterations on Channa punctatus renal tissue exposed to zinc and concluded that these alterations are severe enough to cause impairment to kidney functions. The alterations observed on kidneys of $D$. rerio exposed to NPOH and surfactants were considered moderate and severe and widely distributed through the organ (Table 11). 
Table 8: Mean of Histological Alteration Index (HAI) of D. rerio liver after exposure do different concentrations of NPOH in triplicate (n=15 animals/ group).

\begin{tabular}{|c|c|c|c|c|c|c|}
\hline Replicate & Blank & $125 \mu \mathrm{g} / \mathrm{L}$ of Surfactants & $25 \mu \mathrm{g} / \mathrm{L}$ of $\mathrm{NPOH}$ & $35 \mu \mathrm{g} / \mathrm{L}$ of $\mathrm{NPOH}$ & $50 \mu \mathrm{g} / \mathrm{L}$ of $\mathrm{NPOH}$ & $125 \mu \mathrm{g} / \mathrm{L}$ of $\mathrm{NPOH}$ \\
\hline 1 & 0 & 0.6 & 35.6 & 34 & 34.2 & 31,6 \\
\hline 2 & 0 & 2.6 & 33.4 & 31.6 & 56.2 & 32 \\
\hline 3 & 0 & 5 & 33.4 & 55.6 & 31.8 & 12,2 \\
\hline Mean \pm SD & $0.0 \pm 0.0$ & $2.73 \pm 1.27$ & $34.13 \pm 0.73$ & $40.4 \pm 7.63$ & $40.73 \pm 7.8$ & $25.26 \pm 6.5$ \\
\hline
\end{tabular}

Table 9: Occurrence of alterations in percentage on liver of treated groups exposed to different concentrations of NPOH.

\begin{tabular}{|c|c|c|c|c|c|c|}
\hline Alterations & Stage & $125 \mu \mathrm{g} / \mathrm{L}$ of Surfactants & $25 \mu \mathrm{g} / \mathrm{L}$ of $\mathrm{NPOH}$ & $35 \mu \mathrm{g} / \mathrm{L} \mathrm{of} \mathrm{NPOH}$ & $50 \mu \mathrm{g} / \mathrm{L}$ of $\mathrm{NPOH}$ & $125 \mu \mathrm{g} / \mathrm{L} \mathrm{of} \mathrm{NPOH}$ \\
\hline HCD & I & 26.6 & 100 & 93.3 & 66.6 & 60 \\
\hline OCLA & I & 0 & 100 & 93.3 & 93.3 & 46.6 \\
\hline ONLA & I & 13.3 & 100 & 100 & 100 & 80 \\
\hline ICV & I & 0 & 86.6 & 20 & 46.6 & 40 \\
\hline INV & I & 0 & 20 & 6.6 & 33.3 & 26.6 \\
\hline $\mathrm{CV}$ & I & 40 & 86.6 & 100 & 86.6 & 93.3 \\
\hline DRFN & I & 0 & 20 & 33.3 & 20 & 6.6 \\
\hline IRFBV & I & 0 & 6.6 & 0 & 33.3 & 33.3 \\
\hline IRVBV & I & 0 & 66.6 & 66.6 & 33.3 & 66.6 \\
\hline GR & I & 46.6 & 60 & 86.6 & 73.3 & 100 \\
\hline BS & I & 13.3 & 40 & 60 & 46.6 & 80 \\
\hline Нyp & II & 6.6 & 73.3 & 80 & 86.6 & 80 \\
\hline DBV & II & 0 & 0 & 6.6 & 60 & 6.6 \\
\hline DBC & II & 0 & 26.6 & 20 & 13.3 & 13.3 \\
\hline NV & II & 0 & 66.6 & 93.3 & 33.3 & 46.6 \\
\hline CD & II & 26.6 & 100 & 100 & 100 & 100 \\
\hline ND & II & 0 & 100 & 93.3 & 100 & 100 \\
\hline NA & II & 0 & 33.3 & 20 & 40 & 13.3 \\
\hline CDis & II & 0 & 46.6 & 93.3 & 40 & 0 \\
\hline Necrosis & III & 0 & 100 & 100 & 93.3 & 26.6 \\
\hline
\end{tabular}

Each value represents, in percentage, number of damage fishes in relation to total fishes (N=15) for each concentration. HCD=hepatic cordon disarrangement; OCLA= outline cell loss or atypia; ONLA=outline nuclear loss or atypia; ICV=increase in cell volume; INV= increase in nuclear volume; $\mathrm{CV}=$ cytoplasmic vacuolation; DRFN=decrease in relative frequency of nuclei; IRFBV=increase in the relative frequency of blood vessels; IRVBV=increase on relative volume of blood vessels; $\mathrm{GR}=$ glycogen reduction; $\mathrm{BS}=$ biliary stagnation; $\mathrm{Hyp}=$ hyperemia; $\mathrm{DBV}=$ disruption of blood vessels; $\mathrm{DBC}=\mathrm{degeneration}$ bile canaliculi; $\mathrm{NV=nuclear}$ vacuolation; $\mathrm{CD}=$ cytoplasmic degeneration; $\mathrm{ND}=$ nuclear degeneration; $\mathrm{NA}=$ nuclear atrophy; $\mathrm{CDis}=\mathrm{cellular}$ disruption. 
Table 10: Mean of Histological Alteration Index (HAI) of D. rerio kidneys after exposure do different concentrations of NPOH in triplicate (n=15 animals/ group).

\begin{tabular}{|c|c|c|c|c|c|c|}
\hline Replicate & Blank & $\mathbf{1 2 5} \boldsymbol{\mu g} / \mathbf{L}$ of Surfactants & $\mathbf{2 5} \boldsymbol{\mu g} / \mathbf{L} \mathbf{~ o f ~ N P O H}$ & $\mathbf{3 5} \boldsymbol{\mu g} / \mathbf{L ~ o f ~ N P O H}$ & $\mathbf{5 0} \boldsymbol{\mu g} / \mathbf{L ~ o f ~ N P O H}$ & $\mathbf{1 2 5} \boldsymbol{\mu g} / \mathbf{L} \mathbf{~ o f ~ N P O H}$ \\
\hline 1 & 0 & 31.8 & 53.8 & 34 & 33.8 \\
\hline 2 & 0 & 31.8 & 54.2 & 56 & 36.2 \\
\hline 3 & 0 & 8.2 & 54.2 & 55.4 & 56 \\
\hline Mean \pm SD & $0.0 \pm 0.0$ & $23.9 \pm 7.86$ & $54.0 \pm 0.13$ & $48.4 \pm 7.23$ & $42 \pm 7.03$ \\
\hline
\end{tabular}

Table 11: Occurrence of alterations in percentage on kidney of treated groups exposed to different concentrations of NPOH.

\begin{tabular}{|c|c|c|c|c|c|c|}
\hline Alterations & Stage & $125 \mu \mathrm{g} / \mathrm{L}$ of Surfactants & $25 \mu \mathrm{g} / \mathrm{L}$ of $\mathrm{NPOH}$ & $35 \mu \mathrm{g} / \mathrm{L}$ of $\mathrm{NPOH}$ & $50 \mu \mathrm{g} / \mathrm{L} \mathrm{of} \mathrm{NPOH}$ & $125 \mu \mathrm{g} / \mathrm{L}$ of $\mathrm{NPOH}$ \\
\hline LCO & I & 86.6 & 100 & 100 & 100 & 93.3 \\
\hline HTC & I & 33.3 & 100 & 100 & 100 & 86.6 \\
\hline TDis & I & 46.6 & 80 & 86.6 & 100 & 46.6 \\
\hline GD is & I & 0 & 6.6 & 6.6 & 0 & 0 \\
\hline IBCS & I & 6.6 & 33.3 & 33.3 & 26.6 & 13.3 \\
\hline DBCS & I & 66.6 & 80 & 60 & 80 & 80 \\
\hline DGC & I & 73.3 & 80 & 93.3 & 66.6 & 86.6 \\
\hline DRFG & I & 20 & 13.3 & 40 & 26.6 & 46.6 \\
\hline DilBV & I & 60 & 20 & 46.6 & 46.6 & 0 \\
\hline ITL & I & 53.3 & 93.3 & 80 & 86.6 & 53.3 \\
\hline TO & I & 60 & 53.3 & 33.3 & 73.3 & 66.6 \\
\hline SDTH & II & 33.3 & 93.3 & 100 & 100 & 13.3 \\
\hline TD & II & 46.6 & 100 & 100 & 100 & 66.6 \\
\hline GD & II & 0 & 46.6 & 73.3 & 80 & 60 \\
\hline CDTC & II & 60 & 100 & 100 & 100 & 93.3 \\
\hline NDTC & II & 60 & 100 & 100 & 100 & 93.3 \\
\hline Hyp & II & 60 & 73.3 & 100 & 86.6 & 93.3 \\
\hline RBV & III & 6.6 & 73.3 & 6.6 & 40 & 0 \\
\hline $\mathrm{Nec}$ & III & 46.6 & 100 & 100 & 100 & 40 \\
\hline
\end{tabular}

Each value represents, in percentage, number of damage fishes in relation to total fishes (N=15) for each concentration.LCO=Loss of cellular outline or atypical cellular outline on lymphoid tissue; LDH= low degeneration of hyaline; HTC=hypertrophy of tubular cells; TDis= tubular disorganization; GDis=glomerular disorganization; IBCS= increase on Bowman's capsule space; DBCS= decrease on Bowman's capsule space; DGC= dilatation of glomerular capillaries; PRT= presence of regenerated tubules or "new" nephrons; PSG= presence of several granules PAS positive on tubular cells; $\mathrm{DRFG}=$ decrease in the relative frequency of glomerulus; DilBV= dilatation of blood vessels; ITL= increase in tubuar lumen; TO= tubular obstruction; SDTH=severe degeneration on tubular hyaline; TD=tubular degeneration; GD=glomerular degeneration; CDTC= cytoplasmic degeneration of tubular cells; NDTC= nuclear degeneration of tubular cells; PLTBC= presence of lymphoid tissue on Bowman's capsule; Hyp= hyperemia; RBV= rupture of blood vessels; Nec= necrosis. 

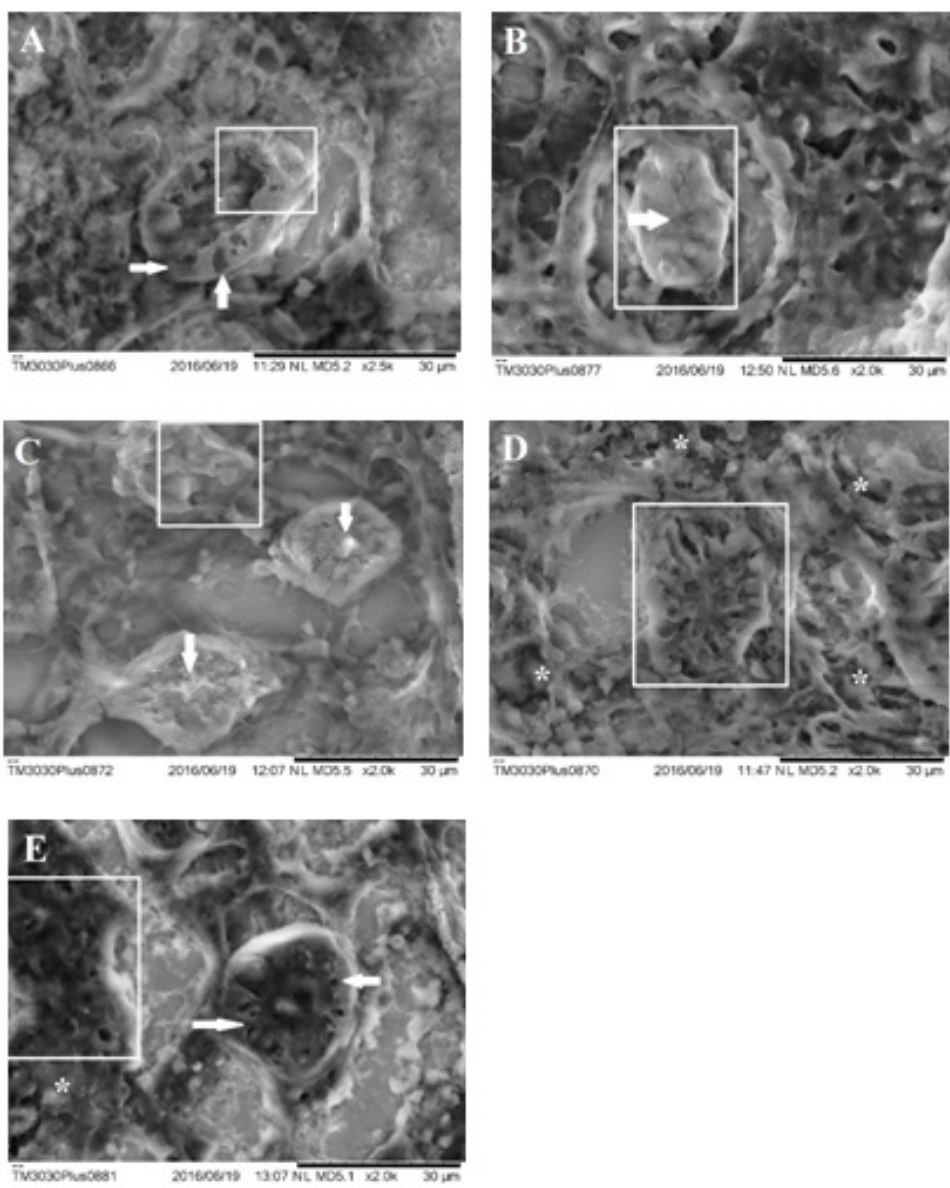

Figure 10: Scanning electron microscopy of kidney of Danio rerio (zebrafish). A) Kidney of Danio rerio exposed to concentration of $125 \mu \mathrm{g} / \mathrm{L}$ of surfactant. Observe slight hyaline degeneration (white arrows) cytoplasmic degeneration of tubular cells (white marked area). B) Kidney of Danio rerio exposed to concentration of $125 \mu \mathrm{g} / \mathrm{L}$ of NPOH. Observe hypertrophy of tubular cells (white marked area) and tubular obstruction

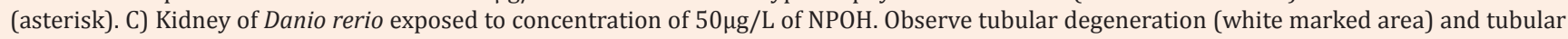
obstruction (white arrows). D) Kidney Danio rerio exposed to concentration of $35 \mu \mathrm{g} / \mathrm{L}$ of NPOH. Observe severe hyaline degeneration (are marked) and necrosis points (asterisk). E) Kidney of Danio rerio exposed to concentration of 35 $\mu \mathrm{g} / \mathrm{L}$ of NPOH. Observe severe hyaline degeneration (white arrows) and necrosis (white marked area).

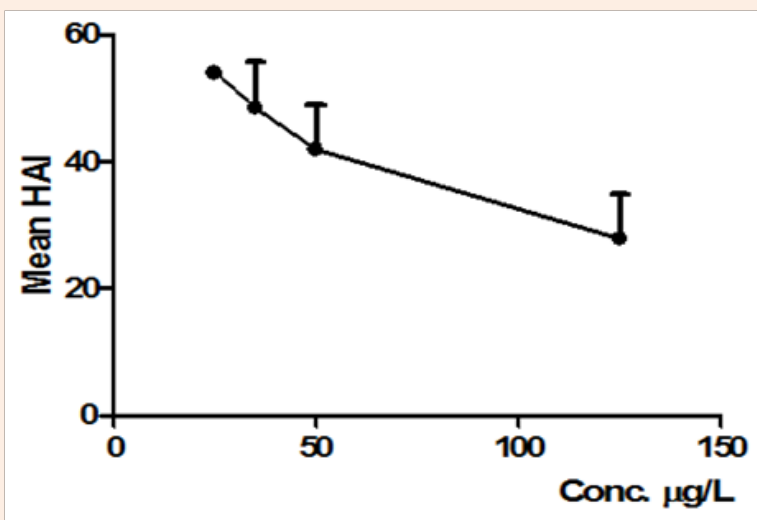

Figure 11: Mean HAI obtained on D. rerio kidneys exposed to NPOH $(25,35$, and 50 e $125 \mu \mathrm{g} / \mathrm{L})$. Each point represents mean $\pm \mathrm{SD}(\mathrm{n}=15$ animals/ group). Anova followed by Tukey-Kramer test. There were no statistically significant alterations in the kidneys of $D$. rerio when compared to exposure concentration of $125 \mu \mathrm{g} / \mathrm{L}$ of surfactant with exposure concentrations $\mathrm{NPOH}$. 


\section{Conclusion}

Exposure of D. rerio to different concentrations $(25,35,50$ and $125 \mu \mathrm{g} / \mathrm{L}$ ) of NPOH during $48 \mathrm{~h}$ induced behavioural alterations and LC50 was estimated at $33.4 \mu \mathrm{g} / \mathrm{L}$. Concentrations of 25 and $35 \mu \mathrm{g} / \mathrm{L}$ of NPOH induced major injury to gills tissue when compared to other NPOH concentrations ( 50 and $125 \mu \mathrm{g} / \mathrm{L}$ ) and surfactants $(125 \mu \mathrm{g} / \mathrm{L})$. Concentrations of 25,35 and $50 \mu \mathrm{g} / \mathrm{L}$ of $\mathrm{NPOH}$ induced major injury to hepatic tissue, when compared to surfactants $(125 \mu \mathrm{g} / \mathrm{L})$, while not significant alteration was observed regarding comparison among theses concentrations. Concentrations of 25, 35 and $50 \mu \mathrm{g} / \mathrm{L}$ of NPOH did not induce any significant alterations on kidneys, when compared to surfactants $(125 \mu \mathrm{g} / \mathrm{L})$ and neither when compared among them. Our data support previous toxicity patterns previously observed for nanoformulations and xenobiotics.

\section{Acknowledgement}

Authors would like to thank CAPES (no 3292/2013 AUXPE), and CNPq Proc. 402332/2013-0 for the financial support.

\section{References}

1. Rand GM, Petrocelli SR (1985) Fundamentals of aquatic toxicology: methods and applications. Hemisphere Publishing Corporation, Newyork, USA

2. Barron MG, Hoffman DJ, Rattner BA, Burton GA, Cairns J (1995) Bioaccumulation and bio concentration in aquatic organisms. Handbook of Ecotoxicology Boca Raton, Lewis Publishers, USA, 652666.

3. Sloman KA, Scott GR, Diao Z, Rouleau C, Wood CM (2003) Cadmium affects the social behaviour of rainbow trout, Oncorhynchs mykiss. Aquat Toxicol 65(2): 171-185.

4. Best JD, Alderton WK (2008) Zebrafish: An in vivo model for the study of neurological diseases. Neurop Dis Treat 4(3): 567-576.

5. Mcgrath P, Li CQ (2008) Zebrafish: a predictive model for assessing drug-induced toxicity. Drug Discov Today 13(9-10): 394-401.

6. Langheinrich U, Hennen E, Stot G, Vacun G (2002) Zebra fish as a model organism for the identification and characterization of drugs and genes affecting p53 signalling. Curr Biol 12(23): 2023-2028.

7. Zhang WX (2003) Nanoscale iron particles for environmental remediation: an overview. J Nanop Res 5(3): 323-332.

8. Rubinstein AL (2006) Zebra fish assays for drug toxicity screening Expert Opin Drug Metab Toxicol 2(2): 231-240.

9. Heath AG (1995) Water pollution and fish physiology $\left(2^{\text {nd }}\right.$ edn) Florida: Lewis Publishers, USA.

10. Lins JAPN, Kirschnik PG, Queiroz VS, Círio SM (2010) Uso de peixes como biomarcadores para monitoramento ambiental aquático. Rev Acad Ciênc Agrár Ambient Curitiba 8: 469-484.

11. Clemente Z, Castro VLSS, Moura MAM, Jonsson CM, Fraceto LF (2013) Exposição de embriões de Danio rerio a nano-tio2 sob diferentes condições de iluminação. VII Workshop de Nanotecnologia Aplicada ao Agronegócio, 537-538.

12. Lee KL, Nallathamby PD, Browning LM, Osgood CJ, Xu XHN (2007) In vivo imaging of transport and biocompatibility of single silver nanoparticles in early development of zebrafish embryos. ACS Nano 1(2): 133-143.

13. Medina C, Santos Martinez MJ, Radomski A, Corrigan OI, Radomski MW
(2007) Nanoparticles: pharmacological and toxicological significance. Br J Pharmacol 150(5): 552-558.

14. Sharma HS (2007) Nanoneuroscience: emerging concepts on nanoneurotoxicity and nanoneuroprotection. Nanomedicine (Lond) 2(6): 753-758.

15. Gelb MH, Tamanoi F, Yokoyama K, Ghomashchi KE, Gould MN (1996) The inhibition of protein prenyltransferases by oxygenated metabolites of limonene and perillyl alcohol. Cancer Lett 91(2): 169175 .

16. Holstein SA, Hohl RJ (2003) Monoterpene regulation of Ras and Rasrelated protein expression. J Lipid Res 44(6): 1209-1215.

17. Nakada M, Nakada S, Demuth T, Tran NL, Hoelzinger DB, et al. (2007) Molecular targets of glioma invasion. Cell Mol Life Sci 64(4): 458-478.

18. Xu M, Floyd HS, Greth SM, Chang WL, Lohman K, et al. (2004) Perillyl alcohol-mediated inhibition of lung cancer cell line proliferation: potential mechanisms for its chemotherapeutic effects. Toxicol Applied Pharmacol 195(2): 232-246.

19. Fernandes J, Da Fonseca CO, Teixeira A, Gattass CR (2005) Perillyl alcohol induces apoptosis in human glioblastoma multiforme cells. Oncol Rep 13(5): 943-947.

20. Yeruva L, Pierre KJ, Elegbede A, Wang RC, Carper SW (2007) Perillyl alcohol and perillic acid induced cell cycle arrest and apoptosis in non small cell lung cancer cells. Cancer Lett 257(2): 216-226.

21. Yuri T, Danbara N, Tsujita Kyutoku M, Kiyozuka Y, Senzaki H, et al. (2004) Perillyl alcohol inhibits human breast cancer cell growth in vitro and in vivo. Breast Cancer Res Treat 84(3): 251-260.

22. Da Fonseca CO, Landeiro JA, Clark SS, Quirico-Santos T, da Costa CM, et al. (2006) Recent advances in the molecular genetics of malignant gliomas discloses targets for antitumor agent perillyl alcohol. Surg Neurol 65(supp 1): S1-S8.

23. Matos JM, Schmidt CM, Thomas HJ, Cummings OW, Weibke EA, et al. (2008) A pilot study of perillyl alcohol in pancreatic cancer. J Surg Res 147(2): 194-199.

24. Rajesh D, Stenzel RA, Howard SP (2003) Perillyl Alcohol as a Radio/ Chemo sensitizer in Malignant Glioma. Journal of Biological Chemistry 278: 35968-35978.

25. Loutrari H, Hatziapostolou M, Skouridou V, Papadimitriou E, Roussos C, et al. (2004) Perillyl alcohol is an angiogenesis inhibitor.J Pharmacol Exp Ther 311(2): 568-575

26. Clark SS, Perman SM, Sahin MB, Jenkins GJ, Elegbede JA (2002) Antileukemia activity of perillyl alcohol ( $\mathrm{POH})$ : uncoupling apoptosis from G0/G1 arrest suggests that the primary effect of $\mathrm{POH}$ on Bcr/Abl cells is to induce cell arrest. Leukemia 16(2): 213-222.

27. Elegbede JA, Flores R, Wang RC (2003) Perillyl alcohol and perillaldehyde induced cell cycle arrest and cell death in BroTo and A549 cells cultured in vitro. Life Sciences 73(22): 2831-2840.

28. Wiserman DA, Werner SR, Crowell PL (2007) Cell Cycle Arrest by the Isoprenoids Perillyl Alcohol, Geraniol, and Farnesol Is Mediated by p21Cip1 and p27Kip1 in Human Pancreatic Adenocarcinoma Cells. The Journal of Pharmacology and Experimental Therapeutics 320(3): $1163-1170$

29. Clark SS (2006) Perillyl Alcohol Induces c-Myc-Dependent Apoptosis in Bcr/Abl-Transformed Leukemia Cells. Oncology 70(1): 13-18.

30. Balassiano ITPS, Silva NH, Cabral MC, Gibaldi D, Bozza MFC, et al. (2002) Effects of perillyl alcohol in glial C6 cell line in vitro and antimetastatic activity in chorioallantoic membrane model. Intern J Mol Med 10(6): 785-788. 
31. Wagner DS, Mullins MC (2002) Modulation of BMP Activity in DorsalVentral Pattern Formation by the Chordin and Ogon Antagonists. Developmental Biology 245(1): 109-123.

32. Salazar MDA, da Silva RF, da Fonseca CO, Lagrota-Candido J, QuiricoSantos T (2014) Intranasal administration of perillyl alcohol activates peripheral and bronchus-associated immune system in vivo. Arch Immunol Ther Exp 62(1): 59-66.

33. Fernandes CP, Mascarenhas MP, Zibetti FM, Lima BG, Oliveira RPRF, et al. (2013) HLB value, an important parameter for the development of essential oil phytopharmaceuticals. Brazilian Journal of Pharmacognosy 23(1): 108-114.

34. ISO (2006) International Organization for Standardization.

35. Lead JR, Wilkinson KJ (2006) Aquatic colloids and nanoparticles: current knowledge and future trends. Environ Chem 3: 159-171.

36. Schwaiger J, Wanke R, Adam S, Pawert M, Honnen W, et al. (1997) The use of histopatological indicators to evaluate contaminant-related stress in fish. Journal of Aquatic Ecosystem Stress and Recovery 6:7586.

37. Poleksic V, Mitrovic-Tutundzic (1994) Fish gills as a monitor of sub lethal and chronic effects of pollution In: Müller R \& Lloyd R. Sub lethal and chronic effects of pollutants on freshwater fish. Fishing New Books, USA, 339-352.

38. Rodrigues ECR, Ferreira AM, Vilhena JCE, Almeida FB, Cruz RAS, et al. (2014) Development of a larvicidal nanoemulsion with Copaiba (Copaifera duckei) oleoresin. Rev Bras Farmacogn 24: 699-705.

39. Leong W, Lai O, Long K, Man YBC, Misran M, et al. (2011) Preparation and characterisation of water-soluble phytosterol nanodispersions. Food Chemistry 129(1): 77-83.

40. Solé I, Solans C, Maestro A, Gutiérrez JM (2012) Study of Nanoemulsion formation by diluition of microemulsions. Journal of Colloid and Interface Science 376(1): 133-269.

41. WC Griffin (1949) Classification of surface-active agents by HLB. J Soc Cosmet Chem 1: 311-326.

42. Ribeiro LC (2013) Investigação do efeito ictiotóxico do extrato etanolico da raiz de Spilanthes acmella (jambu) em zebrafish através da análise eletrofisiológica e comportamental. 61 f. Dissertação (Mestrado) - Universidade Federal do Pará, Instituto de Ciências Biológicas, Belém. Programa de Pós-Graduação em Neurociências e Biologia Celular, Brasil.

43. Little EE, Fairchild JF, De Lonay AJ (1993) Behavioural methods for assessing impacts of contaminants on early life stage fishes. American Fisheries Society Symposium 14: 67-76.

44. Fink G, Schreck CB (2007) Encyclopedia of Stress. Academic Press, San Diego 3: 68-72.

45. Bilberg K, Hovgaard MB, Besenbacher F, Baatrup E (2012) In Vivo Toxicity of Silver Nanoparticles and Silver Ions in Zebrafish (Danio rerio). J of Toxicol 2012: 293784.

46. Chae YJ, Pham CH, Lee J, Bae E, Yi J (2009) Evaluation of the toxic impact of silver nanoparticles on Japanese medaka (Oryzias latipes). Aquatic Toxicology 94(4): 320-327.

47. Rigolin-Sá O (1998) Toxicidade do herbicida Roundup (glifosato) e do acaricida Omite (propargito) nas fases iniciais da ontogenia do bagre, Rhandia hilarii (Valenciennes, 1840) (Pimelodidade, Siluriformes). 307f. Tese (Doutorado em Recusos Naturais) Curso de Pós-graduação em Ecologia e Recursos Naturais, Universidade Federal de São Carlos, São Carlos, Brasil.
48. Rudnicki, CAM (2004) Análise qualitativa e quantitativa das histopatológicas causadas pelo organofosforado azodrin $₫ 400$ sobre o tecido branquial do peixe de água doce piaractus mesopotamicus (holmberg, 1887) após exposição subletal. Programa de PósGraduação em Biologia Celular e Molecular, Departamento de Biologia Celular, Setor de Ciências Biológicas da Universidade Federal do Paraná, Curitiba.

49. Meletti PC, Rocha O (2003) Avaliação da degradação ambiental por meio de testes de toxicidade com sedimento e de análises histopatológicas em peixes. Tese (Doutorado). UFSC, São Carlos, São Paulo, Brasil.

50. Heath AG (1987) Water Pollution and Fish Physiology. Boca Raton, CRC Press, USA, p. 385.

51. Muller R, Lloyd R (1994) Sub lethal and chronic effects of pollutants on freshwater fish. Oxford: Fishing News Books, Australia, p. 378.

52. Takashima F, Hibiya T (1984) An Atlas of Fish Histology-Normal and Pathological Features. Kodansha Ltd Tóquio 69(3): 406.

53. Federici G, Shaw BJ, Handy RD (2007) Toxicity of titanium dioxide nanoparticles to rainbow trout (Oncorhynchus mykiss): Gill injury, oxidative stress, and other physiological effects. Aquatic Toxicology 84(4): 415-430.

54. Rahman M, Colque-Navarro P, Kühn I, Huys G, Swings J, et al. (2002) Identification and characterization of pathogenic Aeromonas veronii biovar sobria associated with epizootic ulcerative syndrome in fish in Bangladesh. Applied and Environmental Microbiology 68(2): 650655.

55. Simeonova PP, Opopol N, Luster MI (2007) Nanotechnology Toxicological Issues and Environmental Safety. NATO Science for Peace and Security Series, 15-51.

56. Griffitt RJ, Weil R, Hyndman KA, Denslow ND, Powers K (2007) Exposure to copper nanoparticles causes gill injury and acute lethality in zebrafish (Danio rerio). Environ Sci Technol 41(23): 8178-8186.

57. Griffitt RJ, Hyndman K, Denslow ND, Barber DS (2009) Comparison of molecular and histological changes in zebrafish gills exposed to metallic nanoparticles. Toxicol Sci 107(2): 404-415.

58. Pacheco M, Santos MA (2002) Biotransfomation, genotoxic, and histopathological effects of environmental contaminants in European eel (Anguilla anguilla L.). Ecotoxicol Environ Safe 53(3): 331-347.

59. Castro JS, Silva JS, Freitas LC, Carvalho Neta RNF (2014) Biomarcadores histopatológicos na espécie Hoplias malabaricus (Pisces, Osteichthyes, Erythrinidae) em uma Unidade de Conservação de São Luís (MA). Arq Bras Med Vet Zootec 66(6): 1687-1694.

60. Poleksic V, Karan V (1999) Effects of trifluralin on carp: Biochemical and Histological Evaluation. Ecotox Environ Safe San Diego 43(2): 213-221.

61. Kulkarni AP, Byczkowski (1994) Hepatoxicology. In: E Hodgson LPE (Ed.), Introduction to biochemical toxicology. pp. 459-489.

62. Rabelo AFL (2008) Estudo da toxicidade hepática da transdesidrocrotonina, um diterpeno obtido de Croton cajucara Benth, e de estratégias farmacológicas preventivas em modelos animais. Dissertação (Mestrado em Farmacologia), Universidade Federal do Ceará, Fortaleza-CE, Brasil.

63. Hudes GR, Szarka CE, Adams A, Ranganathan S, Mccauley RA (2000) Phase I pharmacokinetic trial of perillyl alcohol in patients with refractory solid malignancies. Clin Cancer Res 6(8): 3071-3080.

64. Azzoli CG, Miller VA, Ng KK, Krug LM, Spriggs DR (2003) A phase I 
trial of perillyl alcohol in patients with advanced solid tumors. Cancer Chemother Pharmacol 51(6): 493-498.

65. Klingelfus T (2013) Efeitos tóxicos de nanopartículas de dióxido de titânio $\left(\mathrm{Tio}_{2}\right.$ ) e chumbo inorgânico (Pbii) em Rhamdia quelen (siluriformes, heptapteridae). Dissertação Pós-Graduação em Ecologia e Conservação, Setor de Ciências Biológicas, da Universidade Federal do Paraná, Curitiba-PR, Brasil.
66. Hinton DE, Laurén DJ (1990) Integrative histopatological approaches to detecting effects of environmental stressors on fishes. In. ADAMS, SM. (Ed) Biological indicators of stress in fish. American Fisheries Society Symposium 8: 51-66.

67. Srivastava N, Gupta P (2006) Effects of sub-lethal concentrations of zinc on histological changes and bioaccumulation of zinc by kidney of fish Channa punctatus (Bloch). Journal of Environmental Biology 27(2): 211-215. 